\title{
Antimicrobials from Medicinal Plants: An Emergent Strategy to Control Oral Biofilms
}

\author{
Catarina Milho ${ }^{1,+}$, Jani Silva ${ }^{1,2,+}$, Rafaela Guimarães ${ }^{1,+}$, Isabel C. F. R. Ferreira ${ }^{3}{ }^{(\mathcal{O}}$, Lillian Barros ${ }^{3, *}$ \\ and Maria José Alves $1,3, *$ (i)
}

1 AquaValor-Centro de Valorização e Transferência de Tecnologia da Água-Associação, Rua Dr. Júlio Martins n. ${ }^{\circ}$ 1, 5400-342 Chaves, Portugal; catarina.milho@aquavalor.pt (C.M.); jani.silva@aquavalor.pt (J.S.); rafaela.guimaraes@aquavalor.pt (R.G.)

2 Molecular Oncology and Viral Pathology Group, IPO Porto Research Center (CI-IPOP), Portuguese Oncology Institute of Porto (IPO Porto), Rua Dr. António Bernardino de Almeida 865, 4200-072 Porto, Portugal

3 Centro de Investigação de Montanha (CIMO), Instituto Politécnico de Bragança, Campus de Santa Apolónia, 5300-253 Bragança, Portugal; iferreira@ipb.pt

* Correspondence: lillian@ipb.pt (L.B.); maria.alves@ipb.pt (M.J.A.)

+ These authors contributed equally to this work.

check for updates

Citation: Milho, C.; Silva, J.; Guimarães, R.; Ferreira, I.C.F.R.; Barros, L.; Alves, M.J. Antimicrobials from Medicinal Plants: An Emergent Strategy to Control Oral Biofilms. Appl. Sci. 2021, 11, 4020. https:// doi.org/10.3390/app11094020

Academic Editor: Marek Kieliszek

Received: 6 April 2021

Accepted: 26 April 2021

Published: 28 April 2021

Publisher's Note: MDPI stays neutral with regard to jurisdictional claims in published maps and institutional affiliations.

Copyright: (c) 2021 by the authors. Licensee MDPI, Basel, Switzerland. This article is an open access article distributed under the terms and conditions of the Creative Commons Attribution (CC BY) license (https:// creativecommons.org/licenses/by/ $4.0 /)$.

\begin{abstract}
Oral microbial biofilms, directly related to oral diseases, particularly caries and periodontitis, exhibit virulence factors that include acidification of the oral microenvironment and the formation of biofilm enriched with exopolysaccharides, characteristics and common mechanisms that, ultimately, justify the increase in antibiotics resistance. In this line, the search for natural products, mainly obtained through plants, and derived compounds with bioactive potential, endorse unique biological properties in the prevention of colonization, adhesion, and growth of oral bacteria. The present review aims to provide a critical and comprehensive view of the in vitro antibiofilm activity of various medicinal plants, revealing numerous species with antimicrobial properties, among which, twenty-four with biofilm inhibition/reduction percentages greater than $95 \%$. In particular, the essential oils of Cymbopogon citratus (DC.) Stapf and Lippia alba (Mill.) seem to be the most promising in fighting microbial biofilm in Streptococcus mutans, given their high capacity to reduce biofilm at low concentrations.
\end{abstract}

Keywords: medicinal plants; oral diseases; oral biofilm; drug resistance; antibiofilm strategies

\section{Introduction}

Oral diseases triggered by pathogenic bacteria persevere as a worldwide problem with high impact on human health. More than 750 bacteria species inhabit the oral cavity, some of which are opportunistic species capable of causing infections related to oral biofilm. Epithelial cells, dental surfaces and orthodontic prostheses are examples of oral surfaces favorable to the creation of multispecies biofilms that promote the development of infectious diseases, such as dental caries, gingivitis, and periodontitis, which represent some of the most common chronic oral diseases in adults and children [1-4]. Dental caries, a medical term for tooth decay or cavities, are part of a group of polymicrobial diseases caused by specific acid-producing bacteria, mainly Gram-positive species, such as Streptococcus mutans, Streptococcus sobrinus and Lactobacillus spp., responsible for the destruction of the dental enamel and its lower layer, the dentin $[5,6]$. These bacteria metabolize sucrose into organic acids, mainly lactic acid, which dissolve calcium phosphate from the teeth causing decalcification and possible decay [7]. On the other hand, periodontal diseases are characterized by the occurrence of severe gum infections that damage the soft tissue and the bone that supports the tooth, most of which caused by the pathogens Aggregatibacter actinomycetemcomitans, Porphyromonas gingivalis and Prevotella intermedia $[5,8]$.

Several chemical compounds have been used in the control of oral infectious diseases, like chlorhexidine, fluorine and their combinations [9]. Chlorhexidine is generally accepted 
as a chemical antibiofilm agent, widely used in dentistry to preserve the healthy oral microbiome [10]. However, some unwanted side effects have been reported, arising from its use for prolonged periods, which may include tooth pigmentation, burning sensation in the mouth, altered taste, and restocking of the oral cavity by resistant strains [11], the latter being mainly due to an increased resistance to antibiotics and to other synthetic chemicals, with a consequent decrease in their clinical efficacy [2]. Given this, in recent years, one of the adopted strategies to overcome these and other related issues is the use of medicinal plants $[12,13]$, which have been used as traditional treatments for thousands of years and throughout the world, given their composition in natural bioactive compounds with multiple recognized biological activities [14]. There are several reports of antibacterial and/or antibiofilm activity linked to extracts from a huge variety of plants, mostly related with the presence of secondary metabolites such as flavonoids, phenolic acids, and tannins [15], which play an important role in the resistance to various microbial pathogens and in the protection against free radicals and toxins $[16,17]$. Regarding phenolic compounds, several mechanisms through which antimicrobial activity is promoted have been described, since these compounds interact with bacterial proteins and cell membrane structures, damaging and reducing their fluidity, inhibiting the synthesis of nucleic acids, and interfering with the microorganisms' own energy metabolism $[16,18,19]$. On the other hand, the investigation of antibiofilm properties derived from phenolic compounds present in plants has revealed that, in addition to their bactericidal effect, other mechanisms can lead to biofilm suppression, namely through disturbances in its bacterial regulatory mechanisms, such as quorum sensing (QS) [20]. As an example, many catechin-based polyphenols, flavonoids, proanthocyanin oligomers, and some other plant-derived compounds, compromise the formation of biofilm through the inhibition of glucosyltransferases (GTFs) from one of the most important oral pathogens, S. mutans [21].

In modern medicine, natural compounds are considered valuable and with undeniable therapeutic assets, showing reduced toxicity and increased efficiency [22]. Therefore, the search for natural phytochemicals is seen as a good alternative to synthetic substances in the prevention and treatment of oral diseases. The present review focuses on the potential of plant extracts to inhibit the growth and adhesion of oral pathogens, and the development of biofilms, thus reducing the progress of oral diseases.

A literature search in PubMed and Science Direct was conducted using the search terms "oral biofilm", "dental biofilm" "medicinal plants", "aromatic plants", "natural products", "antibiofilm", "cariogenic biofilms" and "natural antimicrobials". Literature analysis included scientific papers published in the last 11 years (between 2010 and 2021). Obtained scientific papers were manually curated and selected by relevance of their findings, namely, selected by relevance of their findings and focusing on antibiofilm activity.

The inclusion criteria for the collected papers (54 papers) were as follows: (1) medicinal plants extracts, (2) oral biofilm-associated bacteria, (3) inhibition of biofilm formation and/or eradication of preformed biofilm.

\section{Oral Microbiome}

The oral cavity has an actual diverse microbiome, comprising bacteria, protozoa, fungi, archaea, and viruses, with the most abundant group (96\%) being composed by bacteria belonging to the phyla Firmicutes, Bacteroidetes, Proteobacteria, Actinobacteria, Spirochaetes, and Fusobacteria $[23,24]$. The remaining microorganisms belong to the phyla Euryarchaeotic, Chlamydia, Chloroflexi, SR1, Sinergistetes, Tenericutes, and TM7. Although present in small percentages, species from the Archaea domain, such as Methanobrevibacter oralis, Methanobacterium curvum/congolense and Methanosarcina mazeii, are also part of the oral microbiome [25]. About fungi, Candida species are the most found, being present in almost $50 \%$ of the healthy world population [26]. Other frequently fungi found in the oral cavity belong to Aspergillus, Saccharomycetales, Cryptococcus, Fusarium genera [27]. When it comes to viruses, the most frequently found include those that cause sores in the oral cavity, chicken pox, herpes simplex, among others [28]. Moreover, Tri- 
chomonas tenax and Entamoeba gingivalis are the main protozoa found as members of the oral microbiome, the majority of which being saprophytes [29].

Microorganisms that make up the oral microbiome can reside on two types of surfaces, the hard faces of the teeth and the soft tissues of the oral mucosa [30]. Usually, these microorganisms are present in the oral cavity in the form of a biofilm, playing an extremely important role in oral homeostasis, maintenance, and prevention of oral pathologies [31]. However, under certain conditions, changes in the composition and properties of the biofilm can lead to oral illnesses, such as tooth decay and periodontitis. Increased sugar intake, for instance, promotes the proliferation of acidogenic and aciduric bacteria, such as S. mutans and Lactobacillus acidophilus, which, in turn, create an acidic environment that stimulates the development of dental caries [32-34]. Other bacteria that are usually present in the tooth biofilm include $P$. gingivalis, Tannerella forsythia and Treponema denticola, closely related to periodontal diseases, which may result from a set of inflammatory conditions that affect the supporting tissues of the teeth [35]. Thus, the biofilm formation may represent the start of the development of different oral diseases.

\section{Oral Biofilm Formation}

In general, biofilm formation encompasses a series of sequential steps (Figure 1), which begins with the formation of a conditioning film on a surface. In the oral cavity, specifically, an acquired salivary surface, composed of glycoproteins and other molecules, is developed on the tooth surface [36].

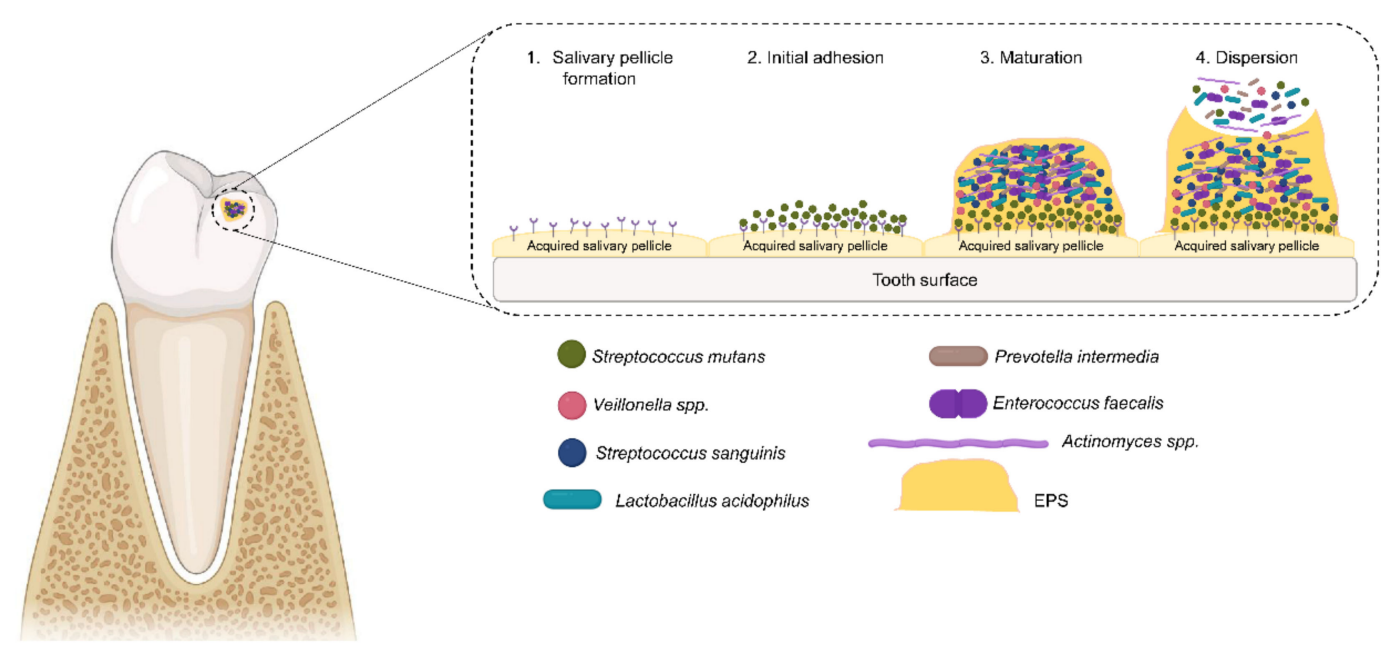

Figure 1. Sequence of pathogenic oral biofilm development. (1) Initially, a salivary pellicle is formed, derived from salivary glycoproteins attached to the tooth surface. (2) Then, initial adhesion starts, as early colonizer bacteria in saliva recognize the binding proteins in acquired pellicle and attach to them. (3) As the biofilm grows, different bacterial species attach, and the biofilm matures. (4) Finally, bacteria disperse from the biofilm and spread to colonize new surfaces. (Created with BioRender.com accessed on 27 April 2021).

Subsequently, a reversible fixation of microorganisms to the tooth occurs, whose approximation of their cell walls occurs randomly or directed through chemotaxis and motility, as well as through weak interactions such as electrostatic and van der Waals forces, and hydrophobic interactions, established between them and the surface [37]. Thus, the mechanisms that occur during the first stages of biofilm formation allow the interaction and adhesion of bacteria to proteins in the acquired salivary film, such as $\alpha$-amylase and glycoproteins rich in proline [38]. The physical-chemical properties of the oral environment, the presence of nutrients, the physiological state of the bacteria and the presence of bacterial structures, such as fimbriae and flagella, also influence bacterial fixation. In dental caries, the main bacterial colonizers that stick to the tooth surface belong to the genus Actinomyces, Streptococcus, Haemophilus, Capnocytophaga, Veillonella and Neisseria [39]. At this stage, if 
the oral environment is unfavorable to fixation, bacteria can be easily removed from the adhered surface. However, under favorable conditions, bacteria can become irreversibly linked, with different forces involved in this process, such as dipole-dipole interactions, hydrogen, ionic and covalent bonds, and hydrophobic interactions [37]. This attachment is strengthened by bacterial surface structures such as ligands located on pili, fimbriae, and fibrillae $[40,41]$. The following production of extracellular polymeric substances (EPS), the most important phase of the irreversible attachment, will support the adhesion of bacteria to oral surfaces. EPS is mainly composed by polysaccharides, containing, also, nucleic and amino acids, glycoproteins and phosphoproteins, phospholipids, uronic acids, and phenolic compounds [42]. In addition to strengthening bacterial adhesion to the tooth surface, EPS is also responsible for reducing diffusional transport, causing decreased growth and metabolism rates of incorporated bacterial cells, nutrient storage, and increased resistance to antimicrobial agents [43]. At the end of this stage, if a physical or chemical procedure is not applied, the bacterial fixation becomes irreversible. Fusobacterium nucleatum, Treponema spp., T. forsythensis, P. gingivalis, and A. actinomycetemcomitans, are some of the main colonizing bacterial species that are late attached to the biofilm in expansion [44]. After this stage, bacterial cells proliferate, communicating with each other through chemical signals, and potentiating the production of EPS. The continuous growth of bacteria leads to the formation of biofilm that can cover the entire exposed surface, and whose complexity increases not only through the constant fixation and growth of these microorganisms, but also through the production of greater amounts of EPS, originating several layers of cells incorporated into the matrix [45]. In the biofilm itself, there are also water-filled channels responsible for transporting nutrients and removing waste products. At this step, the formation of a mature biofilm, with a complex three-dimensional structure, is completed and, as the biofilm matures, the cells become detached and dispersed, as a result of nutrient depletion, decreased $\mathrm{pH}$ or oxygenation, and accumulation of toxic products [46]. Additionally, enzymes that degrade EPS can also be produced by different microorganisms, further increasing the detachment of biofilm cells, which will later colonize new niches and start the formation of new biofilms.

In the oral cavity, the subsistence in a multispecies biofilm confers ecological advantages when compared to biofilms colonized by a single species. Moreover, once in the EPS matrix, oral bacteria are protected from microenvironmental damage, from the host's immune defenses and from antimicrobial agents [47]. The presence of persistent dormant cells in the biofilm is crucial, given their high tolerance to antimicrobial agents, reason why they are pointed out as the main parties responsible for the biofilm recalcitrancy to these agents [48].

\section{Oral Biofilms: From Dental Caries to Systemic Diseases}

Chronic and progressive oral diseases are estimated to affect more than 3.5 million people worldwide. Although preventable, this public health problem can disproportionately affect low-income people and, consequently, their longevity and quality of life, factors directly related to social and economic disparities [49]. As previously mentioned, dental caries, periodontal diseases and other problems related to the oral cavity, result from a complex interaction between the microbiome and the oral microenvironment, the pathogens, and specific characteristics of the host, sharing common risk factors between them $[47,50]$ (Figure 2A). Both the appearance and progression of these pathologies are closely related to bacterial biofilms characteristics, which present themselves as complex microbial groups that interact with each other, triggering immunological/inflammatory responses and modulating the action of antimicrobial agents [51]. 


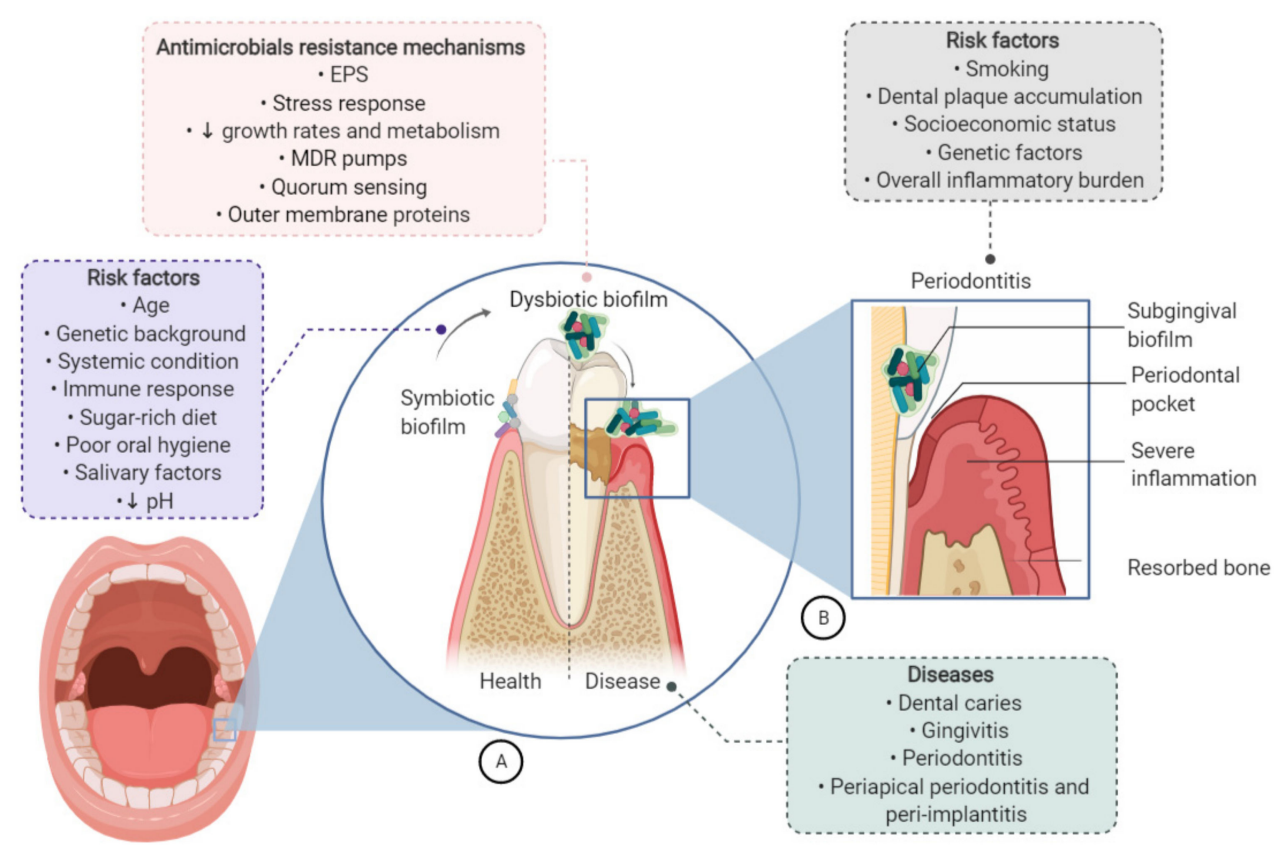

Figure 2. Dysbiosis as a trigger of oral diseases. (A) Development of oral biofilm from health to disease conditions, the associated risk factors, and the antimicrobial resistance mechanisms. (B) Development of periodontitis and related risk factors. (Created with BioRender.com accessed on 27 April 2021).

The extracellular insoluble glucans converted from the dietary sucrose that feeds the assembly of the EPS matrix are essential in bacterial adhesion and subsequent formation of dental plaque, and in the formation of the EPS matrix nucleus of the biofilm, which can be the starting point for the development of diseases such as periodontitis [47,52-54]. Cariogenic biofilms are naturally acidic and hypoxic; however, they are rich in carbohydrates, which creates an environment conducive to the growth of opportunistic microorganisms, such as the lactobacilli, Lactobacillus casei and Lactobacillus reuteri, thus accelerating the development of dental caries [47], which passes from the enamel to the dentin, and may be associated with continuous microbial dysbiosis owed to an increased bacterial diversity and to species with proteolytic capacity, such as F. nucleatum [55].

In contrast, endodontic infections are characterized by the presence of bacterial infections in the tooth pulp that can be caused by initial dental caries. In fact, sequencing of the $16 \mathrm{~S}$ rRNA gene showed that polymicrobial biofilms can be identified within the infected root canals, which are mostly composed of Firmicutes spp. (>50\%) $[50,56,57]$. Thus, the morphological structure of the oral biofilm may vary from case to case, in which the time of infection, the type and availability of nutrients in the oral microenvironment and the arrangement of the established microbiota are at the origin of this structure [58,59].

Periodontitis, in turn, is defined as a chronic inflammatory disease induced by biofilm, that affects the integrity of the periodontium, which consists in the periodontal ligament, gingiva and alveolar bone (Figure 2B). Destructive inflammation of the tissue, as well as increased dysbiosis, results in bone loss, that may culminate in tooth decay and, ultimately, systemic complications. This type of inflammation is associated with variations in the subgingival polymicrobial community, which changes from a predominantly aerobic Grampositive biofilm to a Gram-negative anaerobic biofilm [50]. Chronic periodontitis has been associated with a predominance of "red complex bacteria", namely P. gingivalis, T. forsythia and T. denticola $[50,60]$. The most aggressive forms of this disease can result in faster periodontal destruction and bone loss, modulated by a set of pathogenic species that act in conjunction with A. actinomycetemcomitans strains [50,58].

Increasing evidence has shown that the dysbiotic oral microbiota can not only be a source of oral inflammation, but may also contribute to systemic ones, by releasing toxins or microbial by-products into the bloodstream. Thus, the synergistic effect between oral 
and systemic inflammation is a crucial step for the subsequent damaging effects on various organ systems, increasing the risk of developing oral and non-oral diseases [61] (Figure 3).

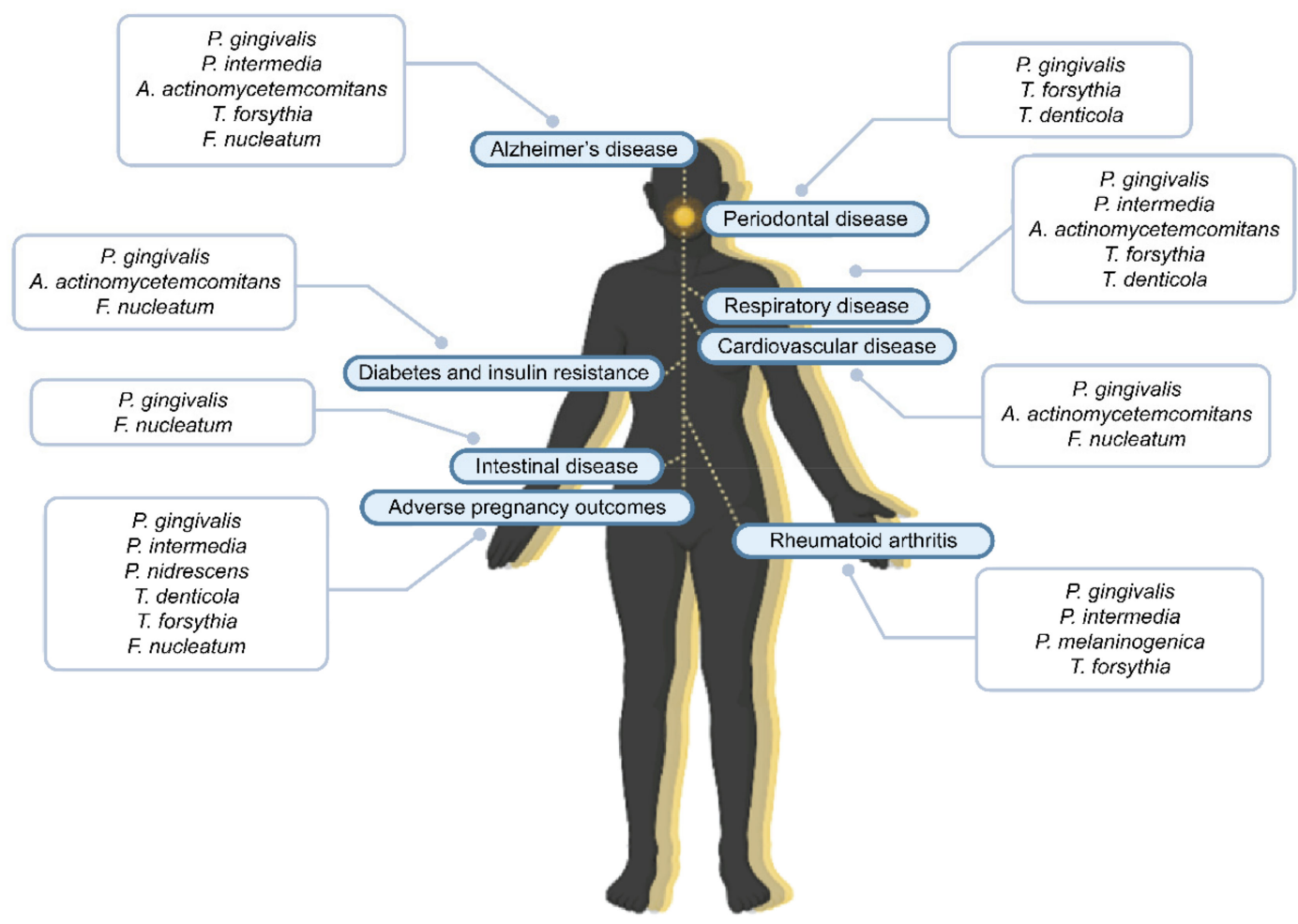

Figure 3. Schematic representation of different systemic diseases and their association with oral keystone pathogens. (Created with BioRender.com accessed on 27 April 2021).

In fact, a meta-analytical study showed that patients with periodontal disease are more susceptible to the development of oral cancer [62]. Recently, a study performed by Michaud et al. [63] also provided supporting data for a positive correlation between periodontal disease and risk of oral, lung, and pancreatic cancers. In line with these information, P. gingivalis was found at significantly higher levels in both oral and esophagus squamous cell carcinoma patients [64]. Moreover, other studies have shown that F. nucleatum can migrate from the oral cavity to the intestinal tract, promoting a pro-inflammatory microenvironment and suggesting a possible role of these bacteria in the development of colorectal cancer $[65,66]$. Also, Alzheimer's disease and diabetes mellitus seem to be bidirectionally associated with periodontal disease [61]. According to Mealey et al. [67], diabetic patients have a 3-fold increase risk of developing periodontitis when compared with healthy controls. On the other hand, Teeuw et al. [68] suggest that periodontal treatments lead to an improvement of glycemic control of type 2 diabetes, which may be related, in part, with periodontal infection and inflammatory response [69]. As so, these data show that periodontal disease management could positively control the glycemic levels in diabetic individuals. Also, Kothari et al. [70] found that individuals with acquired brain injuries had a series of unstable oral, dental and periodontal parameters, translated into generalized chronic periodontitis. In contrast, the systemic production of pro-inflammatory cytokines in response to oral bacterial infection suggests that periodontal disease can lead to cerebral inflammatory state, related to Alzheimer's disease [71,72]. Actually, higher levels of antibodies against $A$. actinomycetemcomitans, $P$. gingivalis, T. forsythia were found in elderly patients with Alzheimer's disease when compared to healthy individuals [72]. Likewise, the presence of periodontopathic virulence factors, namely lipopolysaccharides (LPS) from P. gingivalis and T. denticola, could figure in the development of brain inflammation and, ultimately, in Alzheimer's disease [73]. Other studies have also shown that individuals with periodontal disease had a 1.14 to 2 times greater risk of developing coro- 
nary heart disease when compared to a control group [74]. The presence of oral bacteria DNA, namely P. gingivalis, A. actinomycetemcomitans, T. forsythia, Eikenella corrodens, F. nucleatum and Campylobacter. rectus in atheromatous plaques of endarterectomy, were also detected [75]. Reinforcing the previous results, DNA from periodontal bacteria P. gingivalis, A. actinomycetemcomitans, $P$. intermedia, T. forsythia and cariogenic $S$. mutans, was noticed in atherosclerotic plaques, suggesting that these oral pathogens have the ability to migrate from the oral cavity to distant body sites [76,77]. In addition, the oral cavity, especially the saliva and dental plaque of individuals with periodontal disease, appears to be the source of accumulation and dissemination of pathogens to the lower respiratory tract. Several oral pathogens have already been implicated in lung infections, including A. actinomycetemcomitans, Actinomyces israelii, Capnocytophaga spp., Chlamydophila pneumoniae, Eikenella corrodens, F. nucleatum, Fusobacterium necrophorum, P. gingivalis, P. intermedia and Streptococcus constellatus [78-80]. It has been also reported that periodontal infection increases the likelihood of developing nosocomial pneumonia [81]. Genetic similarities between microorganisms isolated on dental plaque and bronchoalveolar lavage fluid suggest that the former may function as a reservoir for respiratory and/or opportunistic pathogens [82]. Porto et al. [83], in turn, showed that toothed and toothless individuals hospitalized in intensive care units and submitted to orotracheal intubation presented large amounts of A. actinomycetemcomitans, $P$. gingivalis and T. forsythia, suggesting that the oral microenvironment favors the pathogenic bacterial growth. Additional studies also express that systemic dissemination of periodontal-related oral pathogens, endotoxins, and inflammatory mediators can cross the placental barrier and contribute to adverse pregnancy outcomes [84,85], with F. nucleatum and $P$. gingivalis being detected in placental and fetal tissues [86], and in the placenta of preterm delivery patients, respectively $[87,88]$. An increasing number of epidemiological, serological and clinical evidences, observed between the pathogenesis of rheumatoid arthritis and periodontitis, have been presented, with A. actinomycetemcomitans and P. gingivalis being recognized as the main triggers of this disease, associating autoimmunity with periodontal diseases [89]. P. gingivalis is referred as the only human pathogen known to express the peptidyl arginine deiminase enzyme and to produce citrullinated epitopes that are recognized by anti-citrullinated protein antibodies, that ultimately culminate in clinical manifestations of rheumatoid arthritis [50,89].

\section{Biological Properties of Plants}

Traditional knowledge on medicinal plants, used for different health purposes, has attracted much attention among the scientific community due to their effectiveness in the treatment of several diseases [90]. Medicinal plants are a rich source of bioactive compounds, or bionutrients, which may be present in seeds, roots, leaves, flowers, or even in the whole plant, thus assuming themselves as important sources of compounds with characteristics of food additives, flavorings and other valences at an industrial level [91]. Bioactive compounds are secondary metabolites that can be classified based on their composition, the pathway by which they are synthesized, or through their chemical structure. A simple classification of bioactive compounds includes three main groups, consisting of phenolic compounds, terpenoids, and alkaloids, which represent about $90 \%$ of all secondary metabolites [92]. The minor groups of secondary metabolites include saponins, lipids, carbohydrates, ketones, and others [93,94]. Currently, phenolic compounds are among the most studied natural products, given their chemical and structural diversity and bioactive properties $[95,96]$, which may include antioxidant, antimutagenic, antitumor, antiallergenic, anti-inflammatory, antiviral, antiulcer, antidiarrheal, anthelmintic, antihepatitic, and antiproliferative properties $[97,98]$. Medicinal plants are composed of a wide range of phenolic compounds with antimicrobial properties that provide protection against aggressive agents. Some of these compounds can deliver sustainable solutions for combating drug-resistant microorganisms [99]. These secondary metabolites are biosynthesized from the shikimate pathway, containing benzene, hydrogen and oxygen rings, the majority of which being flavonoids, the largest and most studied group of compounds in plants [100]. Flavonoids 
are found to be effective against a wide range of microorganisms, and their antimicrobial activity is thought to be shaped through their ability to form complexes with both extracellular and soluble proteins, as well as with bacterial membranes, increasing their permeability and disruption [101]. In addition, these compounds may also act to inhibit the activities of DNA gyrase and $\beta$-hydroxyacyl-acyl transport protein dehydratase [102]; for example, catechins belonging to this group exhibit inhibitory activity against both Gram-positive and Gram-negative bacteria [103]. In its turn, apigenin showed inhibitory activity to both GTF and fructosyltransferase proteins of $S$. mutans without major impact on bacterial viability [104]. Quercetin derivates inhibited S. mutans biofilm production by reducing the synthesis of both water-soluble and insoluble glucans and suppressing several virulence genes [105]. On the other hand, the antimicrobial mechanism by which terpenoid compounds act is not clearly defined, but is attributed to the rupture of microorganisms membrane [106,107]. Finally, alkaloids, which are biosynthesized from amino acids, such as tyrosine, hold an antimicrobial mechanism attributed to their ability to intercalate with DNA, thereby resulting in impaired cell division and death [108]. The plant-extracted product may exert its antimicrobial activity, not by killing the microorganism itself, but by affecting several key events in the pathogenic process [109,110].

There are several reports on plant extracts activity against a wide range of microbial pathogens from the oral cavity. Some of these studies are focused on the investigation of the ability of plant-derived products to inhibit the formation of biofilms in the oral cavity, interfering and reducing the adhesion of microbial pathogens to different oral surfaces, which constitutes the first step in the formation of dental plaque, and in the progression to cavities and periodontal diseases. It has been shown that crude plant extracts and purified phytochemicals can act as bactericides, inhibiting one or all stages of plaque formation, by interfering with biofilm adhesion/aggregation/formation, or inhibiting the production of glycolytic acid in cariogenic bacteria [111]. Several studies report the polyphenols inhibitory effects on oral biofilm formation and on dental biofilm production and accumulation. Many compounds such as catechins, flavonoids, alkaloids, terpenoids, proanthocyanin oligomers and some other plant-derived compounds, inhibit S. mutans GTFs, one of the crucial virulence factors of $S$. mutans with a key role in the synthesis of glucans, an important component of the biofilm matrix [21]. The use of traditional medicines clearly shows how potential biologically active compounds can suppress pathogens and prevent disease progression [94]. Thus, the use of herbal extracts and their products on a daily basis is a promising and interesting alternative to synthetic compounds in the control of oral diseases.

\section{The Most Promising Medicinal Plant Extracts in the Control of Oral Biofilms}

The antibiotic therapy has reached its limits regarding antimicrobial resistance, threatening the effective prevention and treatment of an increasing range of infections. Thus, new therapeutic approaches based on natural phytochemicals have been the target of several research, considering their bioactive assets, namely antimicrobial properties. Knowing that the number of medicinal plants that potential possess antimicrobial/antibiofilm properties is quite large, only published works investigating the extracts obtained from plants' aerial parts, roots and seeds were considered. Hence, Table 1 presents some of the plant species whose extracts hold compounds with antimicrobial/antibiofilm activity, among others, up to $95 \%$, against specific microorganisms, i.e., extracts with the potential to inhibit biofilm formation and/or eradicate it, with concentrations $<1 \mathrm{mg} \cdot \mathrm{mL}^{-1}$.

One of the described plant species with proven antimicrobial [112], antiulcerative [113] and antifungal [114] activity is Baccharis dracunculifolia D.C., considered to be the most important botanical source of South-Eastern Brazilian propolis [115]. The antibiofilm properties against oral cavity bacteria were studied by Galvão et al. [9], through essential oils extracted from the aerial parts of the plant in question. These authors showed that, for a concentration of $31.2 \mu \mathrm{g} \cdot \mathrm{mL}^{-1}$, B. dracunculifolia extracts present $95 \%$ of inhibition growth of biofilms of $S$. mutans NCTC 1091. The ability of this extract to inhibit biofilm formation seems to be related to its composition in oxygenated sesquiterpenes, such as 
spathulenol and trans-nerolidol, described in the literature as antibiofilm/antimicrobial mediators $[116,117]$.

Different phenolic compounds are responsible for the wide diversity of bioactive properties of plant extracts, which, in addition to their antimicrobial assets, may also take part in the healing process. An example of this statement is the species Camelia japonica L., whose extract holds antioxidant, anti-inflammatory and antimicrobial properties [118-120]. Additionally, Chelidonium majus subsp. asiaticum H.Hara, commonly known as greater celandine, is a medicinal plant widely used in traditional medicine due to its anti-inflammatory and antimicrobial effects [121,122], properties also attributed to the Thuja orientalis L. species, a perennial conifer tree of the family Cupressaceae [123,124]. Choi et al. [125] investigated the antimicrobial and antibiofilm activities of methanolic extracts of C. japonica, C. majus subsp. asiaticum, C. flagelliferum and T. orientalis against oral pathogens. Notably, all these plant extracts were able to inhibit the GTF function of S. mutans ATCC 25175, an important virulence factor in the biofilm formation, by $99.0 \%$, at a concentration of $1.00 \mathrm{mg} \cdot \mathrm{mL}^{-1}$. The total phenolic compounds concentration of these extracts is quite high, which may be the reason of their superior antimicrobial effect [126,127].

The essential oil extracted from Cinnamomum zeylanicum Blume, a perennial tree from which cinnamon is obtained [128], is described in the literature as an antimicrobial agent that acts against various biofilm-forming bacteria present in the oral cavity $[129,130]$, such as S. mutans ATCC 25175. When used in the management of biofilms of S. mutans, the essential oil from C. zeylanicum skin was able to inhibit their formation by up to $99 \%$, at a concentration of $0.224 \mathrm{mg} \cdot \mathrm{mL}^{-1}$ [131]. $\beta$-linalool and $(E)$-cinnamaldehyde are the two main compounds present in this oil, and can be pointed out as responsible for its antibiofilm properties [132,133]. In addition, the essential oils of Coriandrum sativum L., a medicinal plant with nutritional benefits, commonly named coriander, exhibit antibacterial and antibiofilm properties against $S$. mutans, in addition to holding antioxidant and anesthetic properties [134,135]. Galvão et al. [9] used a chemical fraction of C. sativum essential oil as an antibacterial against $S$. mutans UA 159 , at a concentration of $31.2 \mu \mathrm{g} \cdot \mathrm{mL}^{-1}$, being able to inhibit the growth of $S$. mutans biofilms by more than $95 \%$. The fatty alcohol 1-decanol is one of the major components found in C. sativum essential oil, and it has been described as an antibacterial and antibiofilm agent [136,137].

Copaifera pubiflora Benth. is a flowering plant whose oleoresin is widely used in Brazilian medicine due to its anti-inflammatory, analgesic, and antimicrobial properties [138-140]. In a study performed by Moraes et al. [141], oleoresin from C. pubiflora was used as an alternative agent for the removal of oral pathogenic biofilms. This work showed satisfactory data regarding the antimicrobial activity of the used extract against microorganisms normally present in the oral cavity, which included S. sanguinis ATCC 10556 and P. micra clinical isolate (CI), and it was able to eliminate more than $99.9 \%$ of preformed biofilms of these species, at a concentration of $50.0 \mu \mathrm{g} \cdot \mathrm{mL}^{-1}$. The antimicrobial effect of C. pubiflora oleoresin was attributed to the presence of ent-hardwickiic acid, which was found to be the main compound present in this plant [142]. Cymbopogon citratus (DC.) Stapf, in turn, usually known as lemon grass, is a perennial aromatic plant that is cultivated in tropical and sub-tropical regions [143]. Its essential oil has been found to have many different biological properties, including anxiolytic, antibacterial and antibiofilm incomes [144-146]. When it comes to oral health, it has been shown that C. citratus exerts an antibiofilm effect on pathogenic bacteria from the oral cavity. As an example, 93.0\% of growth inhibition of $S$. mutans biofilms was obtained at a concentration of $1.00 \mu \mathrm{g} \cdot \mathrm{mL}^{-1}$ of C. citratus essential oil [147]. In another study, the essential oil from this plant, at a concentration of $0.100 \mu \mathrm{g} \cdot \mathrm{mL}^{-1}$, led to a reduction of more than $95 \%$ of S. mutans ATCC 35668 preformed biofilms [148]. In addition, C. citratus oil was tested against $S$. mutans ATCC 35,688 and L. acidophilus ATCC 4356 single-species biofilms, also inhibiting their growth by more than $95 \%$, although at higher concentrations $\left(26.1 \mathrm{mg} \cdot \mathrm{mL}^{-1}\right.$ and $13.2 \mathrm{mg} \cdot \mathrm{mL}^{-1}$, respectively). Regarding its chemical composition, the compounds that are usually found in C. citra- 
tus essential oil are citral and myrcene, which are described to have good antimicrobial properties [149].

Eucalyptus globulus Labill is an evergreen tree native to Australia whose leaves have been widely used in pharmaceutical products, given their antimicrobial and antioxidant properties [150]. Tsukatani et al. [151] reported that the E. globulus ethanolic extract exhibited up to $99 \%$ eradication activity against $P$. gingivalis JCM 12257 at a minimum biofilm eradication concentration (MBEC) of $49.1 \mu \mathrm{g} \cdot \mathrm{mL}^{-1}$, and S. mutans NBRC13955 at a MBEC of $393 \mu \mathrm{g} \cdot \mathrm{mL}^{-1}$. The extracts of Eucalyptus species were found to equally contain antimicrobial compounds, such as macrocarpals, eucalyptine and 1,8-cineol [152,153]. Macrocarpal $\mathrm{A}, \mathrm{B}$ and $\mathrm{C}$ are phloroglucinol derivatives referred to inhibit virulence factors of the periodontopathic bacteria $P$. gingivalis, including specific cysteine proteinases, which appear to be essential for the growth and survival of this bacterium in the periodontal pocket [152]. The presence of specific groups of bioactive compounds can also influence the progression stages of the oral bacterial biofilm's formation.

Derris reticulata Craib, a climbing medicinal plant used in folk medicine [154], has prenylated flavanones as its main constituents, whose presence has been linked to several pharmacological outcomes, particularly antibacterial activity [154,155]. According to Pulbutr et al. [155], the ethanolic extract from stems of D. reticulata was able to inhibit S. mutans DMST 1877 biofilm formation by up to $99.9 \%$, at the highest tested concentration, $750 \mu \mathrm{g} \cdot \mu \mathrm{L}^{-1}$. These results are in accordance with the capability of D. reticulata to inhibit both sucrose-dependent and independent $S$. mutans adherence in a concentration dependent manner, at sub-MIC concentrations $\left(<625 \mu \mathrm{g} \cdot \mu \mathrm{L}^{-1}\right)$.

Dodonaea viscosa var. angustifolia leaf decoction extracts have been reported to have anti-inflammatory and antimicrobial activity [156,157], and they are traditionally used as mouthwashes for toothaches and related problems [158]. The bioactivities present in this plant can be attributed to the major compounds found in $D$. viscosa extract, namely xylopyranoside; 2,2'-methylenebis [6-(1,1-dimethyl)]-4-methyl); 2-(3-Hydroxy-4-methoxyphenyl)-3,7-dimethoxy-4H-chromen-4-one; trans-3', $4^{\prime}, 5^{\prime}$-Trimethoxy-4-(methylthio)chalcone and stigmasterol [159]. Naidoo et al. [159] studied the inhibitory effect of this plant methanolic extract against $S$. mutans NCTC 1091 biofilm, verifying that biofilm reduction was dependent on the exposure time and concentration.

The tapered roots and rhizomes of Glycyrrhiza glabra L. hold most of the bioactive components responsible for this plant medicinal and culinary features [160]. Its phytochemical compounds, namely glycyrrhizin, an oleanane-type triterpene saponin, stands out as its major constituent with antibiofilm activity $[160,161]$. Suwannakul and Chaibenjawong [162] found that the inhibition pattern and eradication of P. gingivalis biofilm by G. glabra ethanol extract were concentration-dependent. At the concentration of $500 \mu \mathrm{g} \cdot \mathrm{mL}^{-1}$, the extract exhibited up to $90 \%$ inhibition of $P$. gingivalis biofilm formation. In addition, the eradication of $P$. gingivalis biofilm was achieved at a MBEC of $62.5 \mu \mathrm{g} \cdot \mathrm{mL}^{-1}$, being higher at a concentration of $500 \mu \mathrm{g} \cdot \mathrm{mL}^{-1}$. The authors also found that the Rgp- and Kgp-proteinase activities of $P$. gingivalis, which are important virulence factors, were also reduced by approximately 50\% [162]. Interestingly, Kim et al. [163] showed that G. glabra main bioactive compound, namely $18 \alpha$-glycyrrhetinic acid, significantly inhibits the $P$. gingivalis LPS-induced endothelial permeability, both in vitro and in vivo assays.

Lippia alba (Mill.) flowering plant which essential oil presents several pharmacological properties such as sedative, analgesic, antispasmodic, anti-inflammatory and antimicrobial assets [164]. In a work published by Tofino-Rivera et al. [148], the essential oil from L. alba was used as an antibacterial agent against $S$. mutans ATCC 35668 biofilms, and it was shown that, at a concentration of $0.100 \mu \mathrm{g} \cdot \mathrm{mL}^{-1}$, this natural product was able to reduce the number of viable cells present in the biofilm by $95.8 \%$. In this case, isomeric monoterpenes geraniol and citral are two of the main components found, which are known to hold antimicrobial properties $[149,165]$.

The Mentha genus includes diverse aromatic herbs that are commonly used in herbal teas, flavoring agent, and as medicinal plants. Infusion, decoction, and distillate water of 
the aerial parts have been used for centuries as tonics, carminative, digestive, stomachic, antispasmodic, and anti-inflammatory preparations [166]. Traditionally, these plants have been also used for teeth whitening, and their distilled oils used to flavor toothpastes and chewing gum, until this day. Knowing this, several works were conducted in order to study the ability of these plants to eliminate oral pathogenic biofilms. As an example, Shafiei et al. [167] investigated the effects of Mangifera sp. and Mentha sp. aqueous extracts towards the eradication of S. sanguinis ATCC BAA-1455 and S. mutans ATCC 25175 biofilms. Both extracts showed to be more effective in reducing the biofilm population of S. mutans than S. sanguinis. At a concentration $0.50 \mathrm{mg} \cdot \mathrm{mL}^{-1}$, Mangifera sp. and Mentha sp. extracts reduced $99.4 \%$ and $98.5 \%$ the S. mutans biofilms, respectively. Previous reports showed that Psidium sp. and Mentha sp. extracts, as well as their mixtures, have antibacterial and anti-adherence activities against $S$. sanguinis and $S$. mutans in single species biofilms [168,169]. Moreover, the phenolic profile of Mangifera sp. extract revealed that quinic acid, benzophenone $C$-glycoside isomer, benzophenone $C$-glycoside and quercetin-3$O$-glucoside were its main compounds, while in the Mentha sp. extract, methyl 2-[cyclohex2-en-1-yl(hydroxy)-methyl]-3-hydroxy-4-(2-hydroxyethyl)-3-methyl- 5-oxoprolinate was mainly found [170], all presenting inhibiting virulence properties of $S$. mutans.

Myrtus communis L. is an important aromatic and medicinal plant species from the Mediterranean area, widely used for culinary, cosmetic, pharmaceutical, therapeutic, and industrial purposes [171]. Antimicrobial and antioxidant proprieties of $M$. communis have been reported in numerous studies [172]. Sateriale et al. [173] described the antibiofilm activity of hydroethanolic extracts from its leaves against the oral pathogens S. mutans ATCC 25175 , S. oralis (CI), S. mitis (CI), and R. dentocariosa (CI). Curiously, the hydroethanolic extract of $M$. communis produced a significant $(p<0.05)$ inhibition in all tested oral pathogens biofilms. MBEC values, assigned to the lowest concentration of each antimicrobial agent that is able to eradicate preformed biofilms, ranged between $40 \mathrm{mg} \cdot \mathrm{mL}^{-1}$ (S. oralis and S. mitis) and $120 \mathrm{mg} \cdot \mathrm{mL}^{-1}$ (S. mutans and R. dentocariosa). In a previous study, the same authors were able to identify gallic acid derivatives, tannins, myricetin, and quercetin derivatives as the most abundant phenolic compounds in the hydroalcoholic extract of M. communis [174]. The authors also refer that the antibiofilm properties of M. communis have been directly correlated with its phenolic compounds' arrangement.

Rhodiola rosea $\mathrm{L}$. is medicinal plant that has been used due to its therapeutic properties and as a potential source of antimicrobial, antioxidant, anti-inflammatory agents, among others $[175,176]$. This plant has been recognized to present a broad spectrum of biological activities mainly attributed to its major phytochemical compounds, which include phenylethanes and phenylpropanoids (rosavin, salidroside, rosin, cinnamyl alcohol, and tyrosol) $[175,177]$. In a study performed by Zhang et al. [178], the $R$. rosea root ethanolic extract inhibited the biofilm formation of $S$. mutans UA159 by $95 \%$, at a concentration of $0.50 \mu \mathrm{g} \cdot \mu \mathrm{L}^{-1}$, with the highest reduction of EPS synthesis being observed at the same concentration. $R$. rosea also suppressed the expression of virulence genes and QS system as well as the enzymatic activity of GTF proteins in both $0.25 \mu \mathrm{g} \cdot \mu \mathrm{L}^{-1}$ and $0.50 \mu \mathrm{g} \cdot \mu \mathrm{L}^{-1}$ concentration groups [178]. At a concentration of $0.12 \mu \mathrm{g} \cdot \mu \mathrm{L}^{-1}$, no significant cytotoxic effect was observed, and $0.50 \mu \mathrm{g} \cdot \mu \mathrm{L}^{-1}$ and $0.25 \mu \mathrm{g} \cdot \mu \mathrm{L}^{-1}$ slightly inhibited the cell proliferation [178].

Rosmarinus officinalis L. is recognized as a fragrant medicinal plant, native to the Mediterranean region and cultivated worldwide. In addition to its therapeutic and prophylactic effects, this plant is extensively used as a condiment, food preservative and for ornamental purposes [179]. Extensive research has been developed regarding the characterization of the antibiofilm properties of this plant. Tsukatani et al. [151] found that the R. officinalis ethanolic extract was able to eliminate P. gingivalis JCM12257 and S. mutans NBRC13955 biofilm formation at a concentration of $195.5 \mu \mathrm{g} \cdot \mathrm{mL}^{-1}$ and $97.8 \mu \mathrm{g} \cdot \mathrm{mL}^{-1}$, respectively. Additionally, the phytochemical profile of this medicinal herb was determined, and it showed that carnosic acid presented the lowest MBEC against $P$. gingivalis $\left(25.0 \mu \mathrm{g} \cdot \mathrm{mL}^{-1}\right)$ and S. mutans $\left(12.5 \mu \mathrm{g} \cdot \mathrm{mL}^{-1}\right)$. This bioactive component is a plastidial catecholic diterpene with recognized antioxidative, anti-inflammatory and antimicrobial 
properties $[179,180]$. Syzygium aromaticum L., another plant traditionally used as a spice and as a food preservative, holds a wide spectrum of pharmacological properties. As reported by Tsukatani et al. [151], the biofilm eradication activity of $S$. aromaticum ethanolic extract against $P$. gingivalis JCM 12,257 and S. mutans NBRC 13,955 was observed, respectively, at a concentration of 435.5 and $871 \mu \mathrm{g} \cdot \mathrm{mL}^{-1}$. Regarding its phytochemical signature, eugenol, eugenol acetate and $\beta$-caryophyllene are acknowledged as antimicrobial components present in this plant extract [181]. Eugenol was reported to inhibit $P$. gingivalis and S. mutans biofilms at higher concentrations, 800 and $>800 \mu \mathrm{g} \cdot \mathrm{mL}^{-1}$, respectively [151]. In addition, other minor compounds, such as $\beta$-caryophyllene, exhibited eradication activities against $P$. gingivalis and $S$. mutans at lower concentrations $\left(400\right.$ and $50 \mu \mathrm{g} \cdot \mathrm{mL}^{-1}$, respectively), and eugenol acetate against $S$. mutans, at $400 \mu \mathrm{g} \cdot \mathrm{mL}^{-1}$ [151].

Spirostachys africana Sond., a tree originally from South America, is traditionally used as a remedy for toothache [182]. Although used as an antibacterial product, its bioactive properties have not been extensively described in the literature. As an example, the dichloromethane:methanol extract from S. africana leaves was used against $S$. mutans ATCC 25175 oral pathogen, being able to inhibit the growth of $S$. mutans biofilms by more than $97 \%$ at a concentration $0.25 \mathrm{mg} \cdot \mathrm{mL}^{-1}$ [183]. Unfortunately, no studies have been found describing the chemical profile of $S$. africana leaf extracts. Another plant commonly used for its interesting properties is Thymus vulgaris L., commonly named thyme, whose essential oil bioactive properties include antioxidant, anti-inflammatory, antitumor, and antimicrobial effects [184]. Several studies have been conducted regarding the antibacterial activity of T. vulgaris essential oil against oral pathogens, namely S. aureus [185]. Interestingly, when used at a concentration of $0.156 \mathrm{mg} \cdot \mathrm{mL}^{-1}$, this essential oil was capable of inhibiting the formation of $S$. aureus biofilms by $96 \%$. The antibiofilm effect of T. vulgaris essential oil may be due to the presence in its composition of different chemical compounds, in particular thymol, a monoterpenoid phenol that is extensively described as having antibiofilm properties [186].

Trachyspermum ammi L., a plant rich in thymol, is a known herb with recognized medical properties, widely cultivated in the west and northwest of Iran [187]. Its seeds hold several medicinal features, including antibacterial, antioxidants and antifungal properties, among others $[188,189]$. With respect to its application as an antibacterial product against oral bacteria, Khan et al. [90] found that, at a $160 \mu \mathrm{g} \cdot \mathrm{mL}^{-1}$ concentration, the ethanolic extract of T. ammi seeds was able to reduce the number of viable cells in S. mutans ATCC 700610 biofilms by $89 \%$. On the other hand, the petroleum ether fraction of the ethanol extract, applied at $40.0 \mu \mathrm{g} \cdot \mathrm{mL}^{-1}$, caused the complete inhibition of S. mutans biofilms growth $(100 \%)$, probably due to its higher concentration in antimicrobial compounds. As mentioned before, thymol, a monoterpenoid phenol, is the major component found in ethanol extracts of T. ammi seeds, which is known to exert antibiofilm effects [186]. 
Table 1. Medicinal plants with verified antimicrobial/antibiofilm activity against oral cavity bacteria, and the respective bioactive compounds present in their extracts.

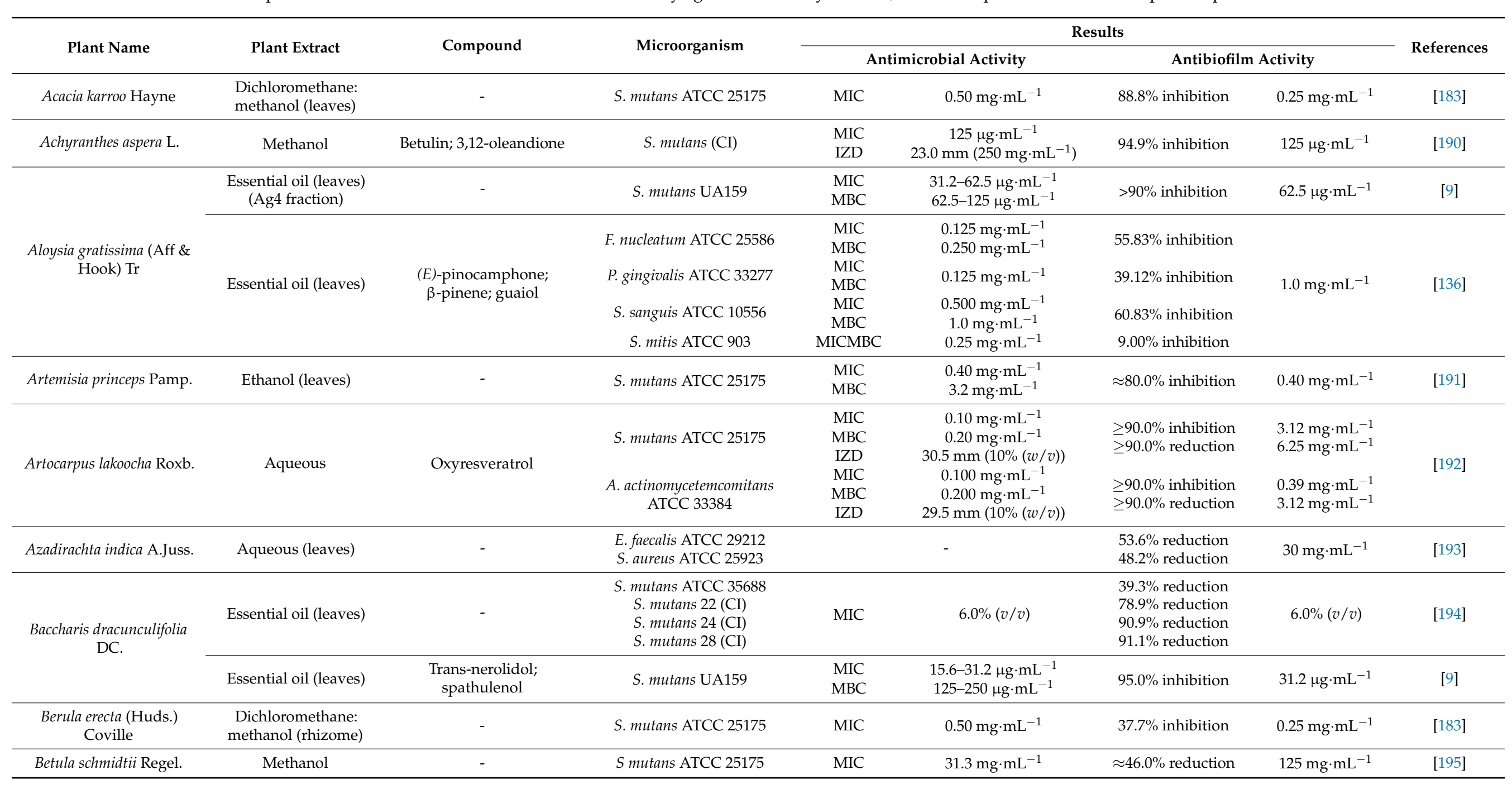


Table 1. Cont.

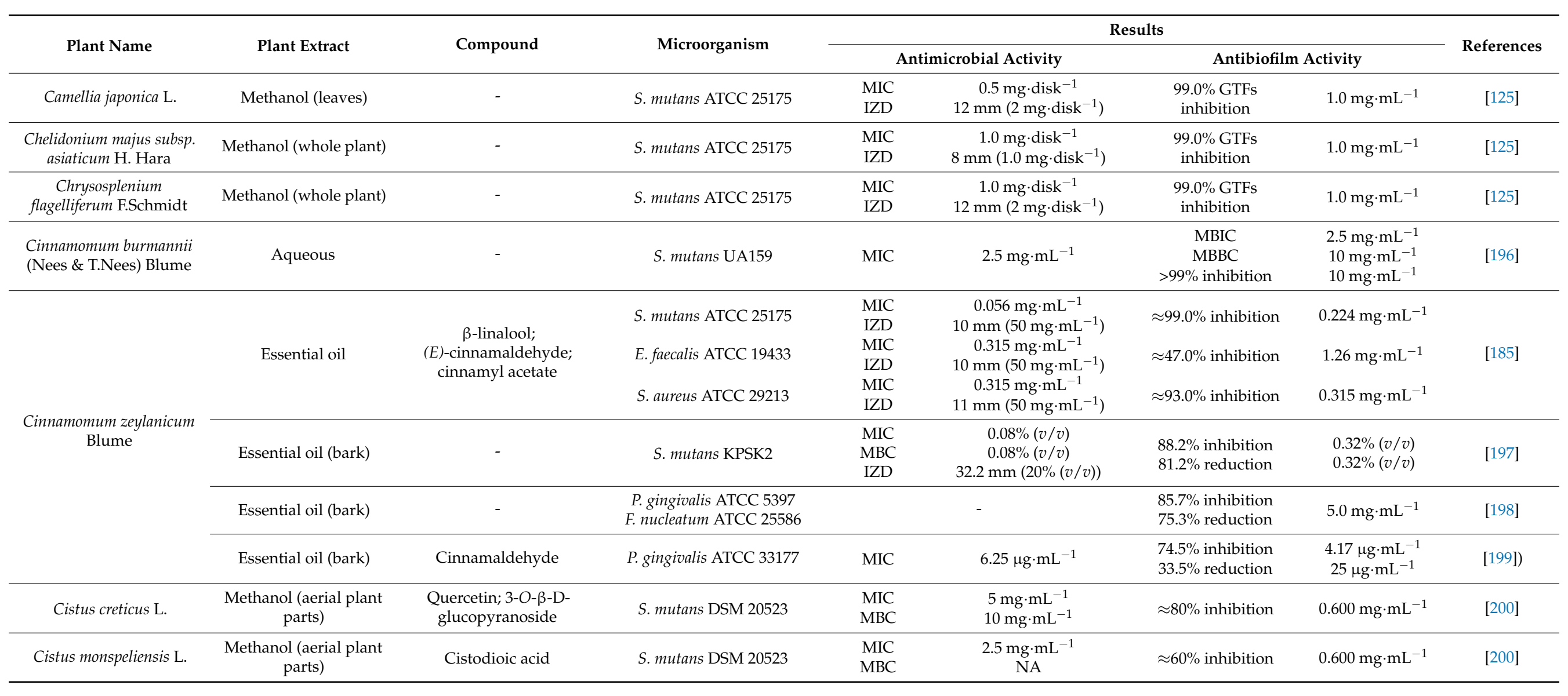


Table 1. Cont.

\begin{tabular}{|c|c|c|c|c|c|c|c|c|}
\hline \multirow{2}{*}{ Plant Name } & \multirow{2}{*}{ Plant Extract } & \multirow{2}{*}{ Compound } & \multirow{2}{*}{ Microorganism } & \multicolumn{4}{|c|}{ Results } & \multirow{2}{*}{ References } \\
\hline & & & & \multicolumn{2}{|c|}{ Antimicrobial Activity } & \multicolumn{2}{|c|}{ Antibiofilm Activity } & \\
\hline \multirow{8}{*}{ Copaifera pubiflora Benth. } & \multirow{8}{*}{ Oleoresin } & \multirow{8}{*}{$\begin{array}{c}\text { Ent-hardwickiic acid; } \\
\text { schistochilic acid B; } \\
\text { ent-7 } \alpha \text {-acetoxy } \\
\text { hardwickiic acid; } \\
\text { (13E)-ent-labda-7,13- } \\
\text { dien-1-5-oic } \\
\text { acid }\end{array}$} & S. sanguinis ATCC 10556 & $\begin{array}{l}\text { MIC } \\
\text { MBC }\end{array}$ & $\begin{array}{l}12.5 \mu \mathrm{g} \cdot \mathrm{mL}^{-1} \\
25.0 \mu \mathrm{g} \cdot \mathrm{mL}^{-1}\end{array}$ & $\begin{array}{l}\mathrm{MBIC}_{50} \\
\text { MBEC }\end{array}$ & $\begin{array}{l}6.25 \mu \mathrm{g} \cdot \mathrm{mL}^{-1} \\
50.0 \mu \mathrm{g} \cdot \mathrm{mL}^{-1}\end{array}$ & \multirow{8}{*}{ [141] } \\
\hline & & & S. sanguinis $(\mathrm{CI})$ & $\begin{array}{l}\text { MIC } \\
\text { MBC }\end{array}$ & $25.0 \mu \mathrm{g} \cdot \mathrm{mL}^{-1}$ & $\mathrm{MBIC}_{50}$ & $6.25 \mu \mathrm{g} \cdot \mathrm{mL}^{-1}$ & \\
\hline & & & S. mutans ATCC 25175 & $\begin{array}{l}\text { MIC } \\
\text { MBC }\end{array}$ & $12.5 \mu \mathrm{g} \cdot \mathrm{mL}^{-1}$ & $\mathrm{MBIC}_{50}$ & $12.5 \mu \mathrm{g} \cdot \mathrm{mL}^{-1}$ & \\
\hline & & & L. paracasei $(\mathrm{CI})$ & $\begin{array}{l}\text { MIC } \\
\text { MBC }\end{array}$ & $12.5 \mu \mathrm{g} \cdot \mathrm{mL}^{-1}$ & $\mathrm{MBIC}_{50}$ & $12.5 \mu \mathrm{g} \cdot \mathrm{mL}^{-1}$ & \\
\hline & & & P. gingivalis ATCC 33277 & $\begin{array}{l}\text { MIC } \\
\text { MBC }\end{array}$ & $\begin{array}{l}12.5 \mu \mathrm{g} \cdot \mathrm{mL}^{-1} \\
50.0 \mu \mathrm{g} \cdot \mathrm{mL}^{-1}\end{array}$ & $\mathrm{MBIC}_{50}$ & $12.5 \mu \mathrm{g} \cdot \mathrm{mL}^{-1}$ & \\
\hline & & & P. gingivalis $(\mathrm{CI})$ & $\begin{array}{l}\text { MIC } \\
\text { MBC }\end{array}$ & $50.0 \mu \mathrm{g} \cdot \mathrm{mL}^{-1}$ & $\mathrm{MBIC}_{50}$ & $100 \mu \mathrm{g} \cdot \mathrm{mL}^{-1}$ & \\
\hline & & & F. nucleatum (CI) & $\begin{array}{l}\text { MIC } \\
\text { MBC }\end{array}$ & $\begin{array}{l}25.0 \mu \mathrm{g} \cdot \mathrm{mL}^{-1} \\
50.0 \mu \mathrm{g} \cdot \mathrm{mL}^{-1}\end{array}$ & $\mathrm{MBIC}_{50}$ & $400 \mu \mathrm{g} \cdot \mathrm{mL}^{-1}$ & \\
\hline & & & P. micra (CI) & $\begin{array}{l}\text { MIC } \\
\text { MBC }\end{array}$ & $\begin{array}{l}12.5 \mu \mathrm{g} \cdot \mathrm{mL}^{-1} \\
25.0 \mu \mathrm{g} \cdot \mathrm{mL}^{-1}\end{array}$ & $\mathrm{MBIC}_{50} \mathrm{MBEC}$ & $\begin{array}{l}25.0 \mu \mathrm{g} \cdot \mathrm{mL}^{-1} \\
50.0 \mu \mathrm{g} \cdot \mathrm{mL}^{-1}\end{array}$ & \\
\hline \multirow{4}{*}{ Coriandrum sativum $\mathrm{L}$. } & Essential oil (leaves) & $\begin{array}{l}\text { 1-decanol, E-2-decen-1-ol; } \\
\text { 2-dodecen-1-ol }\end{array}$ & S. mutans UA159 & $\begin{array}{l}\text { MIC } \\
\text { MBC }\end{array}$ & $\begin{array}{l}15.6-31.2 \mu \mathrm{g} \cdot \mathrm{mL}^{-1} \\
31.2-62.5 \mu \mathrm{g} \cdot \mathrm{mL}^{-1}\end{array}$ & $>95 \%$ inhibition & $31.2 \mu \mathrm{g} \cdot \mathrm{mL}^{-1}$ & [9] \\
\hline & \multirow{3}{*}{ Essential oil (leaves) } & \multirow{3}{*}{$\begin{array}{l}\text { 1-decanol, E-2-decen-1-ol; } \\
\text { 2-dodecen-1-ol }\end{array}$} & P. gingivalis ATCC 33277 & $\begin{array}{l}\text { MIC } \\
\text { MBC }\end{array}$ & $0.125 \mathrm{mg} \cdot \mathrm{mL}^{-1}$ & $39.7 \%$ inhibition & \multirow{3}{*}{$1.0 \mathrm{mg} \cdot \mathrm{mL}^{-1}$} & \multirow{3}{*}{ [136] } \\
\hline & & & S. sanguis ATCC 10556 & $\begin{array}{l}\text { MIC } \\
\text { MBC }\end{array}$ & $\begin{array}{l}0.250 \mathrm{mg} \cdot \mathrm{mL}^{-1} \\
0.500 \mathrm{mg} \cdot \mathrm{mL}^{-1}\end{array}$ & $58.3 \%$ inhibition & & \\
\hline & & & S. mitis ATCC 903 & $\begin{array}{l}\text { MIC } \\
\text { MBC }\end{array}$ & $\begin{array}{l}0.062 \mathrm{mg} \cdot \mathrm{mL}^{-1} \\
0.125 \mathrm{mg} \cdot \mathrm{mL}^{-1}\end{array}$ & $1.5 \%$ inhibition & & \\
\hline Croton urucurana Baill. & $\begin{array}{l}\text { Ethyl acetate-ethanol } \\
\text { (stem bark) }\end{array}$ & - & S. mutans UA159 & & - & $34 \%$ inhibition & $0.007 \mathrm{mg} \cdot \mathrm{mL}^{-1}$ & [201] \\
\hline Curcuma longa $\mathrm{L}$. & Ethanol & - & $\begin{array}{l}\text { P. gingivalis JCM12257 } \\
\text { S. mutans NBRC13955 }\end{array}$ & & - & $\begin{array}{l}99.7 \% \text { reduction } \\
99.1 \% \text { reduction }\end{array}$ & $5.0 \%(v / v)$ & [151] \\
\hline
\end{tabular}


Table 1. Cont.

\begin{tabular}{|c|c|c|c|c|c|c|c|c|}
\hline \multirow{3}{*}{ Plant Name } & \multirow{3}{*}{$\begin{array}{c}\text { Plant Extract } \\
\text { Essential oil (leaves) }\end{array}$} & \multirow{3}{*}{$\begin{array}{c}\text { Compound } \\
\text { Citral; myrcene }\end{array}$} & \multirow{3}{*}{$\begin{array}{c}\text { Microorganism } \\
\text { S. mutans ATCC UA159 }\end{array}$} & \multicolumn{4}{|c|}{ Results } & \multirow{3}{*}{$\begin{array}{c}\text { References } \\
{[147]}\end{array}$} \\
\hline & & & & \multicolumn{2}{|c|}{ Antimicrobial Activity } & \multicolumn{2}{|c|}{ Antibiofilm Activity } & \\
\hline & & & & & - & $93 \%$ inhibition & $1.0 \mu \mathrm{g} \cdot \mathrm{mL}^{-1}$ & \\
\hline $\begin{array}{c}\text { Cymbopogon citratus (DC.) } \\
\text { Stapf }\end{array}$ & Essential oil (leaves) & Geranial; neral; myrcene & $\begin{array}{l}\text { S. mutans ATCC } 35688 \\
\text { L. acidophilus ATCC } 4356\end{array}$ & $\begin{array}{l}\text { MIC } \\
\text { MBC } \\
\text { IZD } \\
\text { MIC } \\
\text { MBC } \\
\text { IZD }\end{array}$ & $\begin{array}{c}2.61 \mathrm{mg} \cdot \mathrm{mL}^{-1} \\
10.54 \mathrm{mg} \cdot \mathrm{mL}^{-1} \\
11 \mathrm{~mm}(100 \%(v / v)) \\
1.32 \mathrm{mg} \cdot \mathrm{mL}^{-1} \\
2.61 \mathrm{mg} \cdot \mathrm{mL}^{-1} \\
8 \mathrm{~mm}(100 \%(v / v))\end{array}$ & $\begin{array}{l}\text { 95\% inhibition } \\
\text { 99.6\% inhibition }\end{array}$ & $\begin{array}{l}26.1 \mathrm{mg} \cdot \mathrm{mL}^{-1} \\
13.2 \mathrm{mg} \cdot \mathrm{mL}^{-1}\end{array}$ & [202] \\
\hline $\begin{array}{l}\text { Cymbopogon martinii } \\
\text { (Roxb.) W. Watson }\end{array}$ & Essential oil & Geraniol; geranyl acetate & $\begin{array}{c}\text { S. mitis }(\mathrm{CI}) \\
\text { E. faecalis }(\mathrm{CI}) \\
\text { S. mitis }+ \text { S. sanguinis }+ \text { E. } \\
\text { faecalis }\end{array}$ & $\begin{array}{l}\text { MIC } \\
\text { MBC } \\
\text { MIC } \\
\text { MBC }\end{array}$ & $\begin{array}{l}0.25 \mathrm{mg} \cdot \mathrm{mL}^{-1} \\
>2.0 \mathrm{mg} \cdot \mathrm{mL}^{-1} \\
0.25 \mathrm{mg} \cdot \mathrm{mL}^{-1} \\
1.0 \mathrm{mg} \cdot \mathrm{mL}^{-1} \\
-\end{array}$ & $\begin{array}{l}28 \% \text { reduction } \\
36 \% \text { reduction } \\
20 \% \text { reduction }\end{array}$ & $1.0 \mathrm{mg} \cdot \mathrm{mL}^{-1}$ & [203] \\
\hline Cyperus articulatus L. & Essential oil (bulbs) & $\begin{array}{c}\alpha \text {-pinene; mustakone; } \\
\alpha \text {-bulnesene }\end{array}$ & $\begin{array}{l}\text { F. nucleatum ATCC } 25586 \\
\text { P. gingivalis ATCC } 33277 \\
\text { S. sanguis ATCC } 10556 \\
\text { S. mitis ATCC } 903\end{array}$ & $\begin{array}{l}\text { MIC } \\
\text { MBC } \\
\text { MIC } \\
\text { MBC } \\
\text { MIC } \\
\text { MBC } \\
\text { MIC } \\
\text { MBC }\end{array}$ & $\begin{array}{l}0.250 \mathrm{mg} \cdot \mathrm{mL}^{-1} \\
0.250 \mathrm{mg} \cdot \mathrm{mL}^{-1} \\
0.250 \mathrm{mg} \cdot \mathrm{mL}^{-1} \\
0.500 \mathrm{mg} \cdot \mathrm{mL}^{-1} \\
0.250 \mathrm{mg} \cdot \mathrm{mL}^{-1} \\
0.500 \mathrm{mg} \cdot \mathrm{mL}^{-1}\end{array}$ & $\begin{array}{l}61.67 \% \text { inhibition } \\
\text { 43.53\% inhibition } \\
63.96 \% \text { inhibition } \\
5.00 \% \text { inhibition }\end{array}$ & $1.0 \mathrm{mg} \cdot \mathrm{mL}^{-1}$ & [136] \\
\hline Derris reticulata Craib & Ethanol (stem) & - & S. mutans DMST 1877 & $\begin{array}{l}\text { MIC } \\
\text { MBC }\end{array}$ & $\begin{array}{l}0.875 \mathrm{mg} \cdot \mathrm{mL}^{-1} \\
1.75 \mathrm{mg} \cdot \mathrm{mL}^{-1}\end{array}$ & $102.8 \%$ inhibition & $750 \mu \mathrm{g} \cdot \mathrm{mL}^{-1}$ & [155] \\
\hline $\begin{array}{l}\text { Dodonaea viscosa var. } \\
\text { angustifólia (L.f.) Benth }\end{array}$ & Methanol (leaves) & $\begin{array}{c}\text { Xylopyranoside; } \\
\text { 2,2'-methylenebis[6-(1,1- } \\
\text { dimethyl)]-4-methyl); } \\
\text { 2-(3-Hydroxy-4- } \\
\text { methoxyphenyl)-3,7- } \\
\text { dimethoxy-4H-chromen- } \\
\text { 4-one; } \\
\text { trans-3',4', } \\
\text { Trimethoxy-4- } \\
\text { (methylthio)chalcone; } \\
\text { stigmasterol }\end{array}$ & S. mutans NCTC 1091 & $\begin{array}{l}\text { MIC } \\
\text { MBC }\end{array}$ & $\begin{array}{c}0.78 \mathrm{mg} \cdot \mathrm{mL}^{-1} \\
3.125 \mathrm{mg} \cdot \mathrm{mL}^{-1}\end{array}$ & $99 \%$ inhibition & $0.78 \mathrm{mg} \cdot \mathrm{mL}^{-1}$ & [159] \\
\hline
\end{tabular}


Table 1. Cont.

\begin{tabular}{|c|c|c|c|c|c|c|c|c|}
\hline \multirow{2}{*}{ Plant Name } & \multirow{2}{*}{ Plant Extract } & \multirow{2}{*}{ Compound } & \multirow{2}{*}{ Microorganism } & \multicolumn{4}{|c|}{ Results } & \multirow{2}{*}{ References } \\
\hline & & & & \multicolumn{2}{|c|}{ Antimicrobial Activity } & \multicolumn{2}{|c|}{ Antibiofilm Activity } & \\
\hline $\begin{array}{c}\text { Englerophytum } \\
\text { magalismontanum(Sond.) } \\
\text { T.D.Penn. }\end{array}$ & $\begin{array}{l}\text { Dichloromethane: } \\
\text { methanol (stems) }\end{array}$ & - & S. mutans ATCC 25175 & MIC & $0.83 \mathrm{mg} \cdot \mathrm{mL}^{-1}$ & $49.28 \%$ inhibition & $0.25 \mathrm{mg} \cdot \mathrm{mL}^{-1}$ & [183] \\
\hline $\begin{array}{l}\text { Erythrina lysistemon } \\
\text { Hutch. }\end{array}$ & $\begin{array}{l}\text { Dichloromethane: } \\
\text { methanol (stems) }\end{array}$ & - & S. mutans ATCC 25175 & MIC & $0.50 \mathrm{mg} \cdot \mathrm{mL}^{-1}$ & $72.54 \%$ inhibition & $0.25 \mathrm{mg} \cdot \mathrm{mL}^{-1}$ & [183] \\
\hline Eucalyptus sp. & Essential oil & - & E. faecalis ATCC 29212 & & - & $\begin{array}{l}71.6 \% \text { reduction } \\
78.5 \% \text { reduction }\end{array}$ & $100 \%(v / v)$ & [204] \\
\hline Eucalyptus galbie & Methanol & - & E. faecalis PTCC 1237 & $\begin{array}{l}\text { MIC } \\
\text { IZD }\end{array}$ & $\begin{array}{c}12.5 \mathrm{mg} \cdot \mathrm{mL}^{-1} \\
9.63 \mathrm{~mm}\left(100 \mathrm{mg} \cdot \mathrm{mL}^{-1}\right)\end{array}$ & $\begin{array}{l}77.7 \% \text { adherence } \\
\text { reduction }\end{array}$ & $6.25 \mathrm{mg} \cdot \mathrm{mL}^{-1}$ & [205] \\
\hline \multirow[t]{2}{*}{ Eucalyptus globulus Labill. } & Ethanol & $\begin{array}{c}\text { Macrocarpal A; } \\
\text { macrocarpal B; } \\
\text { macrocarpal C; } \\
\text { eucalyptin; 1,8-cineole }\end{array}$ & $\begin{array}{l}\text { P. gingivalis JCM12257 } \\
\text { S. mutans NBRC13955 }\end{array}$ & & - & $\begin{array}{l}\text { MBEC } \\
\text { MBEC }\end{array}$ & $\begin{array}{l}49.1 \mu \mathrm{g} \cdot \mathrm{mL}^{-1} \\
393 \mu \mathrm{g} \cdot \mathrm{mL}^{-1}\end{array}$ & [151] \\
\hline & Essential oil (leaves) & 1,8-cineole; $\alpha$-pinene & S. mutans ATCC 700610 & $\begin{array}{l}\text { MIC } \\
\text { IZD }\end{array}$ & $\begin{array}{c}0.013 \mathrm{mg} \cdot \mathrm{mL}^{-1} \\
34.7 \mathrm{~mm}(100 \% \mathrm{v} / \mathrm{v})\end{array}$ & $81.1 \%$ reduction & $2.0 \mathrm{mg} \cdot \mathrm{mL}^{-1}$ & [206] \\
\hline Eucalyptus $x$ urograndis & Essential oil (leaves) & 1,8-cineole; $\alpha$-pinene & S. mutans ATCC 700610 & $\begin{array}{l}\text { MIC } \\
\text { IZD }\end{array}$ & $\begin{array}{c}0.025 \mathrm{mg} \cdot \mathrm{mL}^{-1} \\
23.0 \mathrm{~mm}(100 \%(v / v))\end{array}$ & $35.1 \%$ reduction & $2.0 \mathrm{mg} \cdot \mathrm{mL}^{-1}$ & [206] \\
\hline $\begin{array}{l}\text { Firmiana simplex (L.) } \\
\text { W.Wight }\end{array}$ & Methanol (bark) & - & S. mutans ATCC 25175 & $\begin{array}{l}\text { MIC } \\
\text { IZD }\end{array}$ & $\begin{array}{c}1.0 \mathrm{mg} \cdot \text { disk }^{-1} \\
9 \mathrm{~mm}\left(1.0 \mathrm{mg} \cdot \text { disk }^{-1}\right)\end{array}$ & $\begin{array}{l}\text { 35.7\% GTFs } \\
\text { inhibition }\end{array}$ & $1.0 \mathrm{mg} \cdot \mathrm{mL}^{-1}$ & [125] \\
\hline \multirow[t]{2}{*}{ Foeniculum vulgare Mill. } & Essential oil (seeds) & - & S. mutans KPSK2 & $\begin{array}{l}\text { MIC } \\
\text { MBC } \\
\text { IZD }\end{array}$ & $\begin{array}{c}1.25 \%(v / v) \\
2.50 \%(v / v) \\
9.17 \mathrm{~mm}[20 \%(v / v)]\end{array}$ & $\begin{array}{l}84.4 \% \text { inhibition } \\
69.7 \% \text { reduction }\end{array}$ & $5.0 \%(v / v)$ & [197] \\
\hline & Ethanol & - & $\begin{array}{l}\text { P. gingivalis JCM12257 } \\
\text { S. mutans NBRC13955 }\end{array}$ & & - & $\begin{array}{l}99.9 \% \text { reduction } \\
71.4 \% \text { reduction }\end{array}$ & $5.0 \%(v / v)$ & [151] \\
\hline Geranium sibiricum L. & Methanol (whole plant) & - & S. mutans ATCC 25175 & $\begin{array}{l}\text { MIC } \\
\text { IZD }\end{array}$ & $\begin{array}{c}0.5 \mathrm{mg} \cdot \mathrm{disk}^{-1} \\
15 \mathrm{~mm}\left(2.0 \mathrm{mg} \cdot \mathrm{disk}^{-1}\right)\end{array}$ & $\begin{array}{c}69.3 \% \text { GTFs } \\
\text { inhibition }\end{array}$ & $1.0 \mathrm{mg} \cdot \mathrm{mL}^{-1}$ & [125] \\
\hline Ginkgo biloba L. & Methanol & - & S mutans ATCC 25175 & MIC & $62.5 \mathrm{mg} \cdot \mathrm{mL}^{-1}$ & $\approx 38.5 \%$ reduction & $125 \mathrm{mg} \cdot \mathrm{mL}^{-1}$ & [195] \\
\hline Glycyrrhiza glabra L. & Ethanol (roots) & - & P. gingivalis ATCC 33277 & $\begin{array}{l}\text { MIC } \\
\text { MBC }\end{array}$ & $\begin{array}{l}62.5 \mu \mathrm{g} \cdot \mathrm{mL}^{-1} \\
125 \mu \mathrm{g} \cdot \mathrm{mL}^{-1}\end{array}$ & $\begin{array}{l}\text { 92.3\% inhibition } \\
\text { MBEC }\end{array}$ & $\begin{array}{l}500 \mu \mathrm{g} \cdot \mathrm{mL}^{-1} \\
62.5 \mu \mathrm{g} \cdot \mathrm{mL}^{-1}\end{array}$ & [162] \\
\hline
\end{tabular}


Table 1. Cont.




Table 1. Cont.

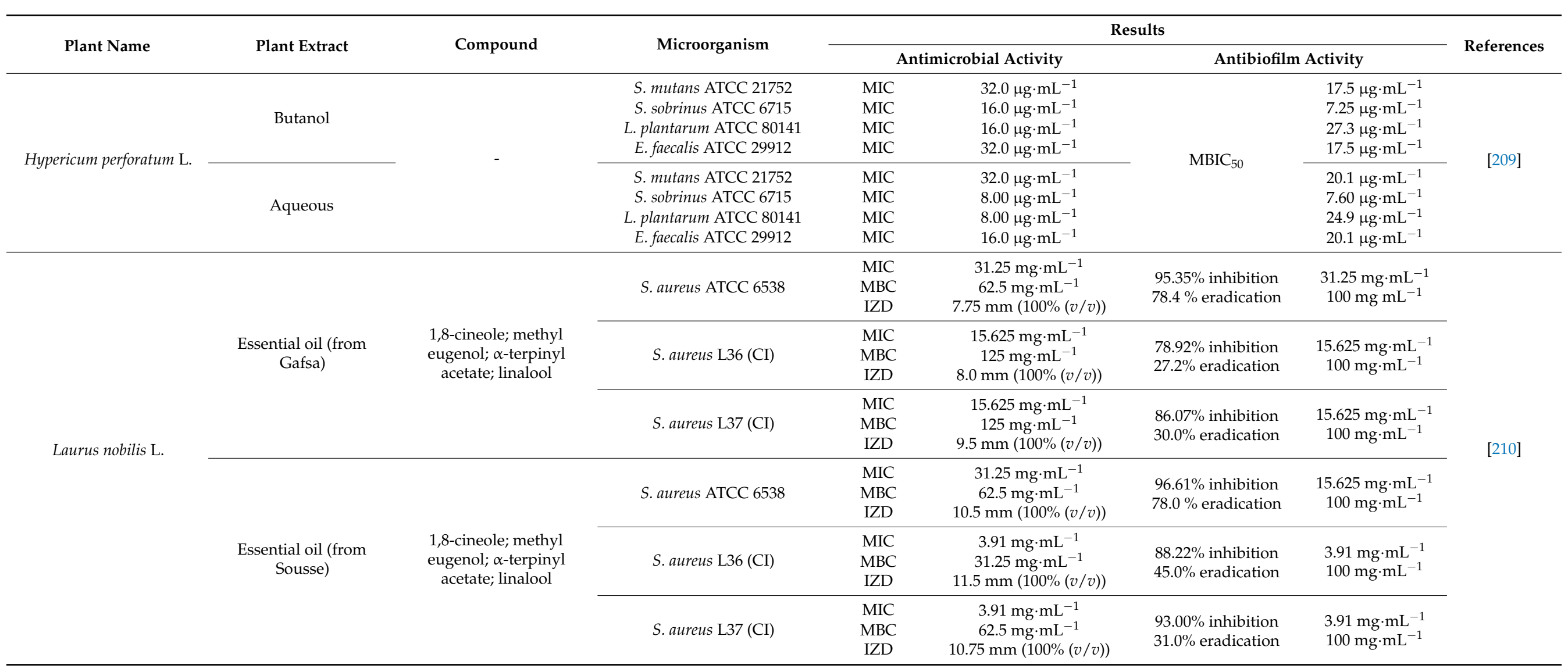


Table 1. Cont.

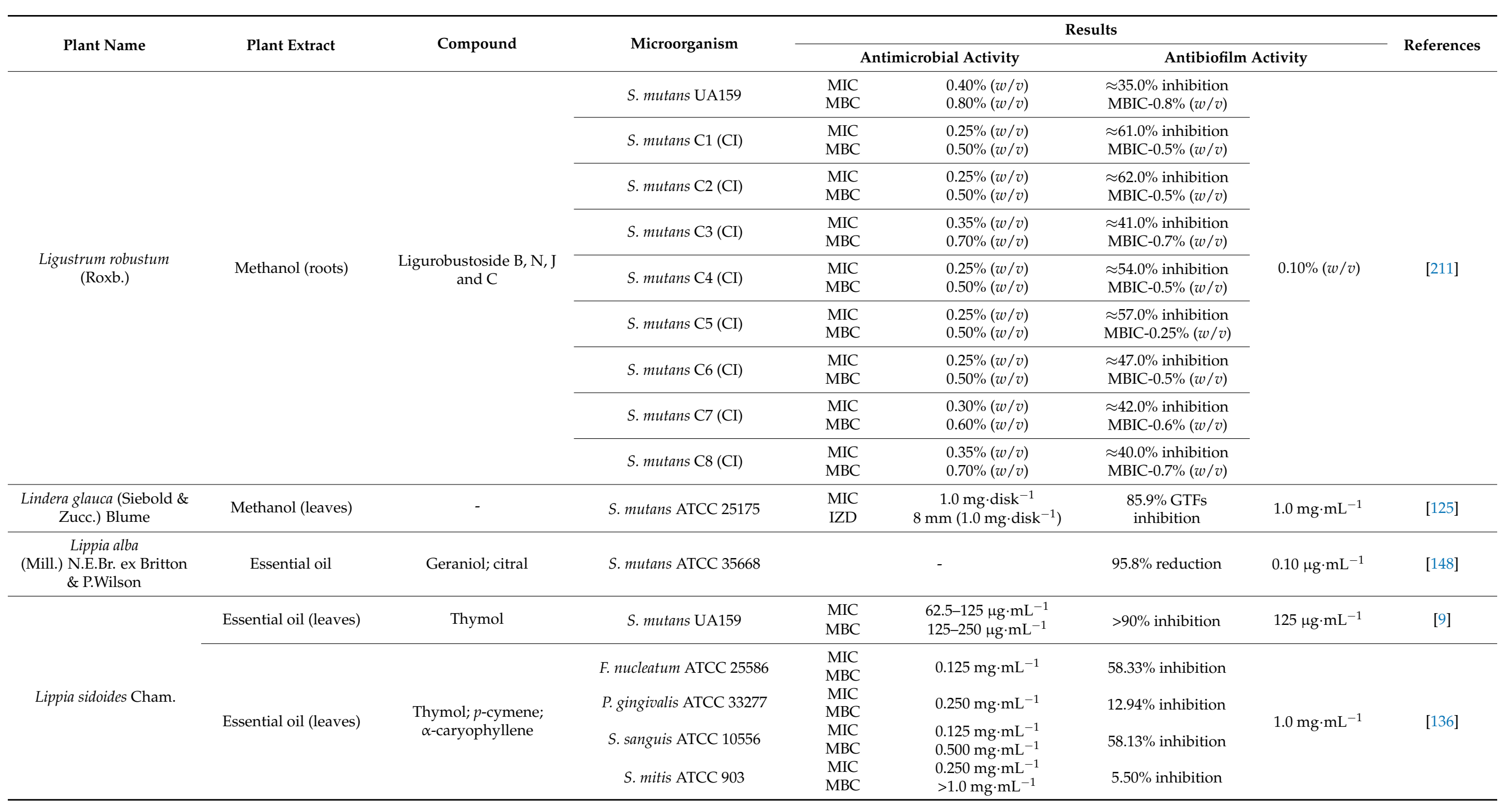


Table 1. Cont.

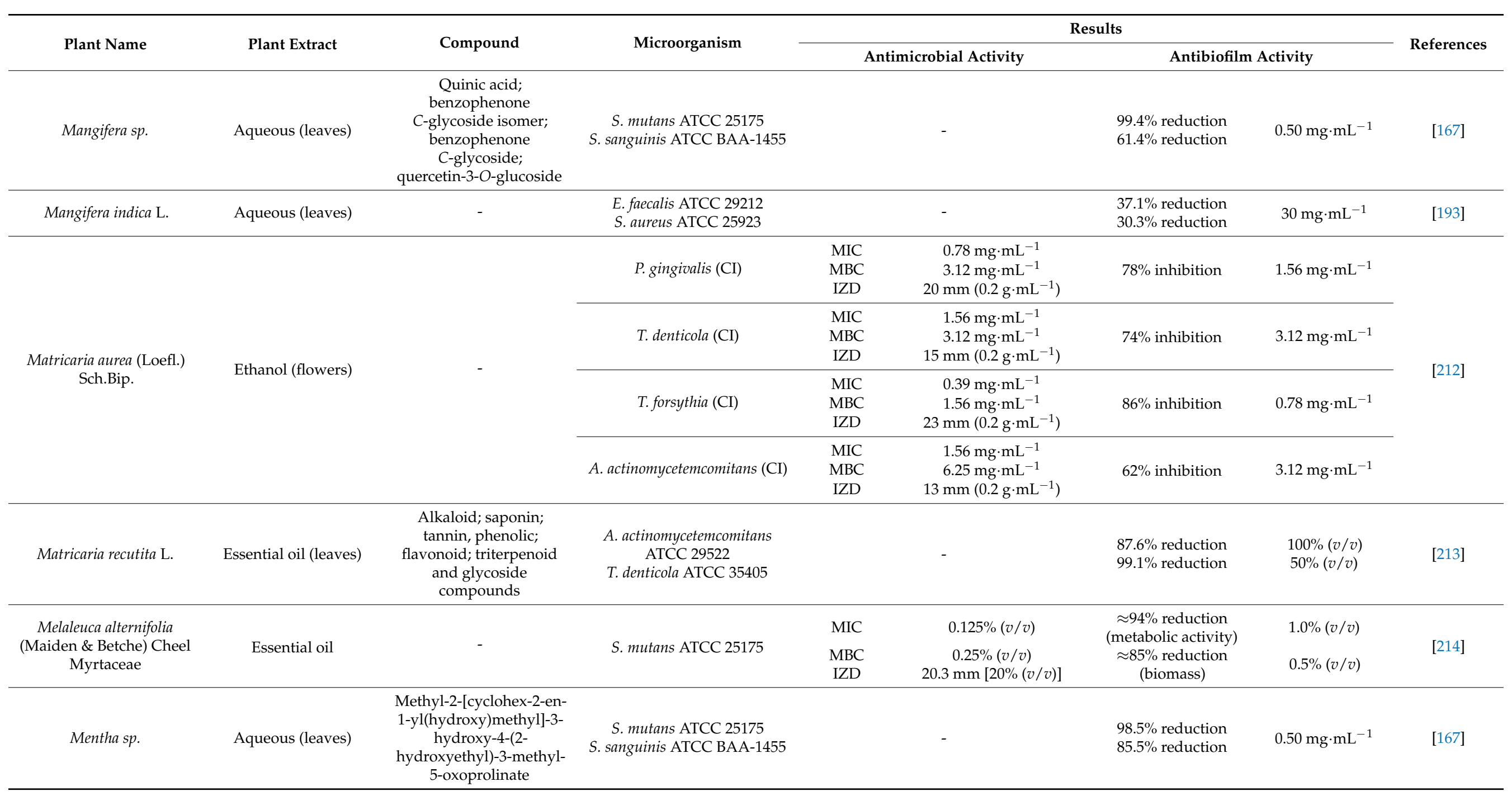


Table 1. Cont.

\begin{tabular}{|c|c|c|c|c|c|c|c|c|}
\hline \multirow{2}{*}{ Plant Name } & \multirow{2}{*}{ Plant Extract } & \multirow{2}{*}{ Compound } & \multirow{2}{*}{ Microorganism } & \multicolumn{4}{|c|}{ Results } & \multirow{2}{*}{ References } \\
\hline & & & & \multicolumn{2}{|c|}{ Antimicrobial Activity } & \multicolumn{2}{|c|}{ Antibiofilm Activity } & \\
\hline \multirow[t]{2}{*}{ Mentha $\times$ piperita $\mathrm{L}$. } & Essential oil (leaves) & - & S. mutans KPSK2 & $\begin{array}{l}\text { MIC } \\
\text { MBC } \\
\text { IZD }\end{array}$ & $\begin{array}{c}1.25 \%(v / v) \\
1.25 \%(v / v) \\
11.33 \mathrm{~mm}(20 \%(v / v))\end{array}$ & $\begin{array}{l}83.42 \% \text { inhibition } \\
71.01 \% \text { reduction }\end{array}$ & $5 \%(v / v)$ & [197] \\
\hline & Essential oil (flowers) & Menthol; menthone & F. nucleatum ATCC 25586 & $\begin{array}{l}\text { MIC } \\
\text { MBC }\end{array}$ & $\begin{array}{l}0.25 \%(v / v) \\
0.5 \%(v / v)\end{array}$ & $>90.0 \%$ inhibition & $0.25 \%(v / v)$ & [215] \\
\hline Mentha spicata L. & Methanol (leaves) & - & S. mutans KPSK2 & $\begin{array}{l}\text { MIC } \\
\text { MBC } \\
\text { IZD }\end{array}$ & $\begin{array}{c}1.25 \%(v / v) \\
1.25 \%(v / v) \\
9.50 \mathrm{~mm}(20 \%(v / v))\end{array}$ & $\begin{array}{l}82.7 \% \text { inhibition } \\
71.5 \% \text { reduction }\end{array}$ & $5.0 \%(v / v)$ & [197] \\
\hline Mikania glomerata Spreng & Essential oil (leaves) & $\begin{array}{c}\text { Germacrene D; } \\
\alpha \text {-caryophyllene; } \\
\text { bicyclogermacrene }\end{array}$ & $\begin{array}{l}\text { F. nucleatum ATCC } 25586 \\
\text { P. gingivalis ATCC } 33277 \\
\text { S. sanguis ATCC } 10556 \\
\text { S. mitis ATCC } 903\end{array}$ & $\begin{array}{l}\text { MIC } \\
\text { MBC } \\
\text { MIC } \\
\text { MBC } \\
\text { MIC } \\
\text { MBC } \\
\text { MIC } \\
\text { MBC }\end{array}$ & $\begin{array}{c}0.25 \mathrm{mg} \cdot \mathrm{mL}^{-1} \\
0.50 \mathrm{mg} \cdot \mathrm{mL}^{-1} \\
0.50 \mathrm{mg} \cdot \mathrm{mL}^{-1} \\
>1.00 \mathrm{mg} \cdot \mathrm{mL}^{-1} \\
0.062 \mathrm{mg} \cdot \mathrm{mL}^{-1} \\
0.125 \mathrm{mg} \cdot \mathrm{mL}^{-1} \\
0.125 \mathrm{mg} \cdot \mathrm{mL}^{-1}\end{array}$ & $\begin{array}{l}58.96 \% \text { inhibition } \\
40.00 \% \text { inhibition } \\
54.79 \% \text { inhibition } \\
\text { 1.00\% inhibition }\end{array}$ & $1.0 \mathrm{mg} \cdot \mathrm{mL}^{-1}$ & [136] \\
\hline $\begin{array}{l}\text { Myracrodruon urundeuva } \\
\text { All. }\end{array}$ & $\begin{array}{l}\text { Hydroalcoholic } \\
\text { (leaves) }\end{array}$ & - & S. mutans ATCC 25175 & $\begin{array}{l}\text { MIC } \\
\text { MBC }\end{array}$ & $2.5 \mathrm{mg} \cdot \mathrm{mL}^{-1}$ & $\begin{array}{l}\text { MBIC } \\
\text { MBEC }\end{array}$ & $\begin{array}{l}1.25 \mathrm{mg} \cdot \mathrm{mL}^{-1} \\
2.5 \mathrm{mg} \cdot \mathrm{mL}^{-1}\end{array}$ & [216] \\
\hline Myrtus communis L. & $\begin{array}{l}\text { Hydroethanolic } \\
\text { (leaves) }\end{array}$ & - & $\begin{array}{l}\text { S. mutans ATCC } 25175 \\
\text { S. oralis }(\mathrm{CI}) \\
\text { S. mitis }(\mathrm{CI}) \\
\text { R. dentocariosa }(\mathrm{CI})\end{array}$ & & - & $\begin{array}{l}\text { MBIC } \\
\text { MBEC } \\
\text { MBIC } \\
\text { MBEC } \\
\text { MBIC } \\
\text { MBEC } \\
\text { MBIC } \\
\text { MBEC }\end{array}$ & $\begin{array}{c}40 \mu \mathrm{g} \cdot \mu \mathrm{L}^{-1} \\
120 \mu \mathrm{g} \cdot \mu \mathrm{L}^{-1} \\
20 \mu \mathrm{g} \cdot \mu \mathrm{L}^{-1} \\
40 \mu \mathrm{g} \cdot \mu \mathrm{L}^{-1} \\
20 \mu \mathrm{g} \cdot \mu \mathrm{L}^{-1} \\
40 \mu \mathrm{g} \cdot \mu \mathrm{L}^{-1} \\
40 \mu \mathrm{g} \cdot \mu \mathrm{L}^{-1} \\
120 \mu \mathrm{g} \cdot \mu \mathrm{L}^{-1}\end{array}$ & [173] \\
\hline \multirow{2}{*}{ Ocimum basilicum L. } & Essential oil (leave) & - & S. mutans KPSK2 & $\begin{array}{l}\text { MIC } \\
\text { MBC } \\
\text { IZD }\end{array}$ & $\begin{array}{c}0.31 \%(v / v) \\
0.31 \%(v / v) \\
14.7 \mathrm{~mm}(20 \%(v / v))\end{array}$ & $\begin{array}{l}86.8 \% \text { inhibition } \\
73.3 \% \text { reduction }\end{array}$ & $1.25 \%(v / v)$ & [197] \\
\hline & Ethanol (seeds) & - & $\begin{array}{l}\text { P. gingivalis JCM12257 } \\
\text { S. mutans NBRC13955 }\end{array}$ & & - & $\begin{array}{l}99.9 \% \text { reduction } \\
90.9 \% \text { reduction }\end{array}$ & $5.0 \%(v / v)$ & {$[151]$} \\
\hline
\end{tabular}


Table 1. Cont.

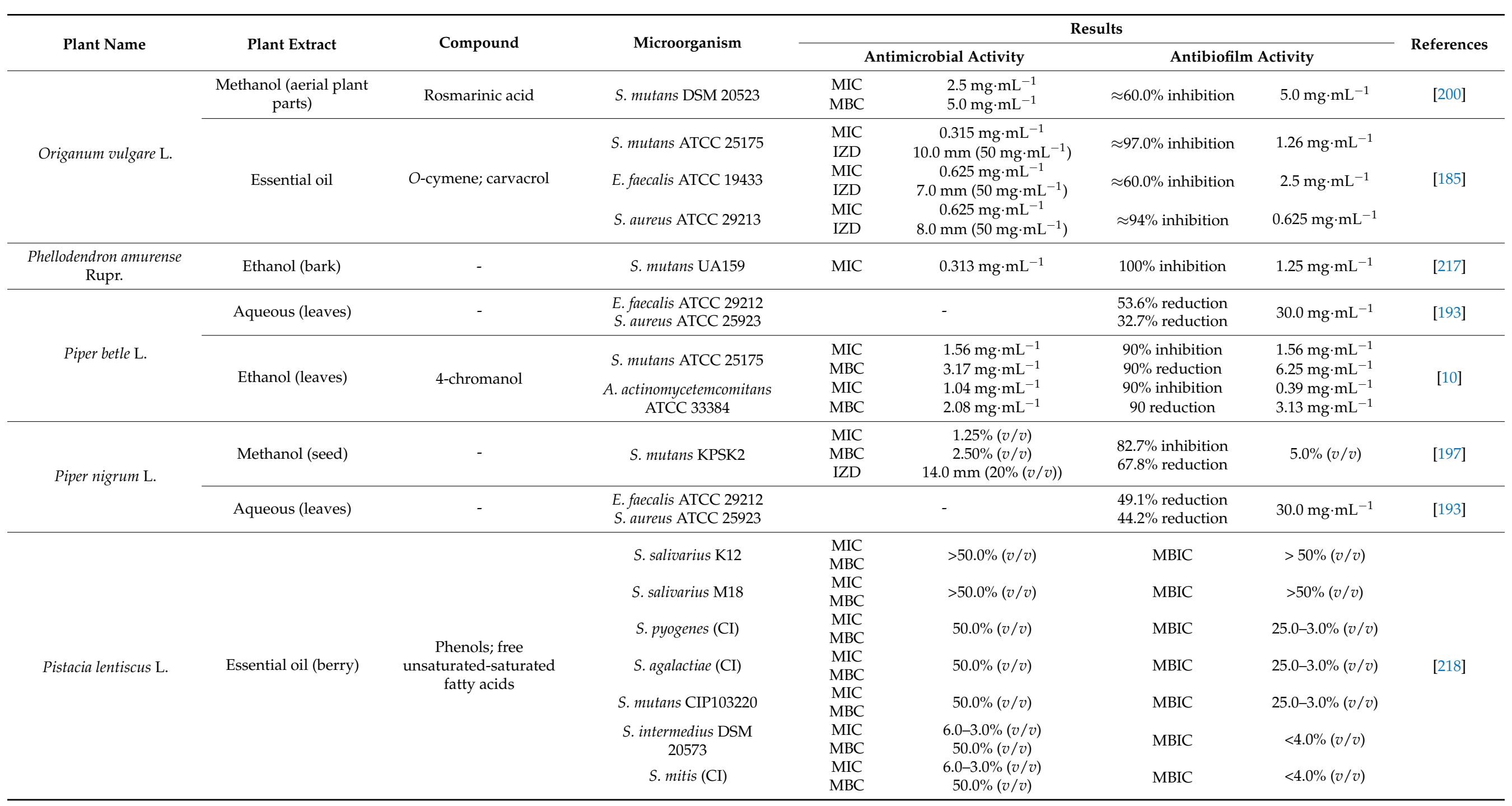


Table 1. Cont.

\begin{tabular}{|c|c|c|c|c|c|c|c|c|}
\hline \multirow{3}{*}{$\begin{array}{c}\text { Plant Name } \\
\text { Pistacia vera L. }\end{array}$} & \multirow{3}{*}{$\begin{array}{c}\text { Plant Extract } \\
\text { Purified oleoresin }\end{array}$} & \multirow{3}{*}{$\begin{array}{c}\text { Compound } \\
\alpha \text {-pinene; } \beta \text {-pinene }\end{array}$} & \multirow{3}{*}{$\begin{array}{c}\text { Microorganism } \\
\text { S. mutans ATCC } 25175 \\
\text { S. sanguinis ATCC } 10556\end{array}$} & \multicolumn{4}{|c|}{ Results } & \multirow{3}{*}{$\begin{array}{c}\text { References } \\
{[219]}\end{array}$} \\
\hline & & & & \multicolumn{2}{|c|}{ Antimicrobial Activity } & \multicolumn{2}{|c|}{ Antibiofilm Activity } & \\
\hline & & & & $\begin{array}{l}\text { MBC } \\
\text { MBC }\end{array}$ & $\begin{array}{l}>2048 \mu \mathrm{g} \cdot \mathrm{mL}^{-1} \\
1024 \mu \mathrm{g} \cdot \mathrm{mL}^{-1}\end{array}$ & $\begin{array}{l}49.4 \% \text { inhibition } \\
71.2 \% \text { inhibition }\end{array}$ & $256 \mu \mathrm{g} \cdot \mathrm{mL}^{-1}$ & \\
\hline Psidium sp. & Aqueous (leaves) & $\begin{array}{l}\text { Methyl quercetin sulfate; } \\
\text { 2,6-dihydroxy-3-methyl- } \\
\text { 4-O-(6"-O-galloyl- } \beta-D- \\
\text { glucopyranosyl)- } \\
\text { benzophenone }\end{array}$ & $\begin{array}{l}\text { S. mutans ATCC } 25175 \\
\text { S. sanguinis ATCC BAA-1455 }\end{array}$ & & - & $\begin{array}{l}93.8 \% \text { reduction } \\
48.6 \% \text { reduction }\end{array}$ & $0.5 \mathrm{mg} \cdot \mathrm{mL}^{-1}$ & [167] \\
\hline \multirow{3}{*}{$\begin{array}{l}\text { Psidium cattleianum } \\
\text { Sabine }\end{array}$} & Aqueous (leaves) & - & P. aeruginosa ATCC 15442 & $\begin{array}{l}\text { MIC } \\
\text { MBC }\end{array}$ & $4.0 \mathrm{mg} \cdot \mathrm{mL}^{-1}$ & - & - & \multirow[t]{3}{*}{ [220] } \\
\hline & \multirow{2}{*}{ Hydroethanol (leaves) } & & E. faecalis ATCC 51299 & MICMBC & $0.5 \mathrm{mg} \cdot \mathrm{mL}^{-1}$ & $>99.9 \%$ reduction & $2.5 \mathrm{mg} \cdot \mathrm{mL}^{-1}$ & \\
\hline & & & P. aeruginosa ATCC 15442 & $\begin{array}{l}\text { MIC } \\
\text { MBC }\end{array}$ & $4.0 \mathrm{mg} \cdot \mathrm{mL}^{-1}$ & $>99.9 \%$ reduction & $40 \mathrm{mg} \cdot \mathrm{mL}^{-1}$ & \\
\hline \multirow{5}{*}{ Punica granatum L. } & \multirow{5}{*}{ Flowers infusion } & \multirow{5}{*}{-} & S. mutans ATCC 35608 & $\begin{array}{l}\text { MIC } \\
\text { MBC }\end{array}$ & $50.0 \mathrm{mg} \cdot \mathrm{mL}^{-1}$ & $84.4 \%$ reduction & $25 \mathrm{mg} \cdot \mathrm{mL}^{-1}$ & \multirow{5}{*}{ [221] } \\
\hline & & & S. sanguinis ATCC 10556 & $\begin{array}{l}\text { MIC } \\
\text { MBC }\end{array}$ & $\begin{array}{l}6.25 \mathrm{mg} \cdot \mathrm{mL}^{-1} \\
25.0 \mathrm{mg} \cdot \mathrm{mL}^{-1}\end{array}$ & $100 \%$ reduction & $1.56 \mathrm{mg} \cdot \mathrm{mL}^{-1}$ & \\
\hline & & & S. sobrinus ATCC 27607 & $\begin{array}{l}\text { MIC } \\
\text { MBC }\end{array}$ & $25.0 \mathrm{mg} \cdot \mathrm{mL}^{-1}$ & $99.9 \%$ reduction & $12.5 \mathrm{mg} \cdot \mathrm{mL}^{-1}$ & \\
\hline & & & S. salivarius ATCC 9222 & $\begin{array}{l}\text { MIC } \\
\text { MBC }\end{array}$ & $\begin{array}{l}25.0 \mathrm{mg} \cdot \mathrm{mL}^{-1} \\
100 \mathrm{mg} \cdot \mathrm{mL}^{-1}\end{array}$ & $86.5 \%$ reduction & $12.5 \mathrm{mg} \cdot \mathrm{mL}^{-1}$ & \\
\hline & & & E. faecalis CIP 55142 & $\begin{array}{l}\text { MIC } \\
\text { MBC }\end{array}$ & $50.0 \mathrm{mg} \cdot \mathrm{mL}^{-1}$ & $56.3 \%$ reduction & $50 \mathrm{mg} \cdot \mathrm{mL}^{-1}$ & \\
\hline $\begin{array}{l}\text { Pyrostegia venusta (Ker } \\
\text { Gawl.) Miers }\end{array}$ & $\begin{array}{l}\text { Hydroalcoholic } \\
\text { (flowers) }\end{array}$ & - & S. mutans ATCC 25175 & $\begin{array}{l}\text { MIC } \\
\text { MBC }\end{array}$ & $\begin{array}{c}500 \mathrm{mg} \cdot \mathrm{mL}^{-1} \\
1000 \mathrm{mg} \cdot \mathrm{mL}^{-1}\end{array}$ & $68.9 \%$ inhibition & $500 \mathrm{mg} \cdot \mathrm{mL}^{-1}$ & [222] \\
\hline $\begin{array}{l}\text { Qualea grandiflora } \\
\text { Mart. }\end{array}$ & $\begin{array}{l}\text { Hydroalcoholic } \\
\text { (leaves) }\end{array}$ & - & S. mutans ATCC 25175 & MIC & $5.0 \mathrm{mg} \cdot \mathrm{mL}^{-1}$ & $\begin{array}{l}\text { MBIC } \\
\text { MBEC }\end{array}$ & $\begin{array}{c}5.0 \mathrm{mg} \cdot \mathrm{mL}^{-1} \\
10.0 \mathrm{mg} \cdot \mathrm{mL}^{-1}\end{array}$ & [216] \\
\hline Rhodiola rosea $\mathrm{L}$. & Ethanol (root) & - & S. mutans UA159 & & - & $\begin{array}{l}\approx 95.0 \% \text { inhibition } \\
\approx 48.6 \% \text { reduction }\end{array}$ & $0.50 \mu \mathrm{g} \cdot \mu \mathrm{L}^{-1}$ & [178] \\
\hline Rosa rugosa Thunb. & Methanol (leaves) & - & S. mutans ATCC 25175 & $\begin{array}{l}\text { MIC } \\
\text { IZD }\end{array}$ & $\begin{array}{c}1.0 \mathrm{mg} \cdot \mathrm{disk}^{-1} \\
12 \mathrm{~mm}\left(2.0 \mathrm{mg} \cdot \mathrm{disk}^{-1}\right)\end{array}$ & $\begin{array}{l}64.9 \% \text { GTFs } \\
\text { inhibition }\end{array}$ & $1.0 \mathrm{mg} \cdot \mathrm{mL}^{-1}$ & [125] \\
\hline
\end{tabular}


Table 1. Cont.

\begin{tabular}{|c|c|c|c|c|c|c|c|c|}
\hline \multirow{2}{*}{ Plant Name } & \multirow{2}{*}{ Plant Extract } & \multirow{2}{*}{ Compound } & \multirow{2}{*}{ Microorganism } & \multicolumn{4}{|c|}{ Results } & \multirow{3}{*}{$\begin{array}{c}\text { References } \\
{[151]}\end{array}$} \\
\hline & & & & & icrobial Activity & Antibiofiln & Activity & \\
\hline \multirow{4}{*}{ Rosmarinus officinalis $\mathrm{L}$. } & Ethanol & $\begin{array}{l}\text { Carnosic acid; carnosol; } \\
\text { rosmarinic acid }\end{array}$ & $\begin{array}{l}\text { S. mutans NBRC13955 } \\
\text { P. gingivalis JCM12257 }\end{array}$ & & - & $\begin{array}{l}\text { MBEC } \\
\text { MBEC }\end{array}$ & $\begin{array}{l}97.8 \mu \mathrm{g} \cdot \mathrm{mL}^{-1} \\
195.5 \mu \mathrm{g} \cdot \mathrm{mL}^{-1}\end{array}$ & \\
\hline & Extract (leaves) & - & $\begin{array}{c}\text { S. aureus ATCC } 6538 \\
\text { E. faecalis ATCC } 4083 \\
\text { S. mutans ATCC } 35688 \\
\text { P. aeruginosa ATCC } 15442\end{array}$ & $\begin{array}{l}\text { MIC } \\
\text { MMC } \\
\text { MIC } \\
\text { MMC } \\
\text { MIC } \\
\text { MMC } \\
\text { MIC } \\
\text { MMC }\end{array}$ & $\begin{array}{c}25 \mathrm{mg} \cdot \mathrm{mL}^{-1} \\
>50 \mathrm{mg} \cdot \mathrm{mL}^{-1} \\
50 \mathrm{mg} \cdot \mathrm{mL}^{-1} \\
>50 \mathrm{mg} \cdot \mathrm{mL}^{-1} \\
25 \mathrm{mg} \cdot \mathrm{mL}^{-1} \\
>50 \mathrm{mg} \cdot \mathrm{mL}^{-1} \\
6.25 \mathrm{mg} \cdot \mathrm{mL}^{-1}\end{array}$ & $\begin{array}{l}99 \% \text { reduction } \\
80 \% \text { reduction } \\
80 \% \text { reduction } \\
70 \% \text { reduction }\end{array}$ & $200 \mathrm{mg} \cdot \mathrm{mL}^{-1}$ & [223] \\
\hline & $\begin{array}{l}\text { Methanol (aerial plant } \\
\text { parts) }\end{array}$ & $\begin{array}{l}\text { 7-methoxyrosmanol, } \\
\text { rosmanol isomers; } \\
\text { rosmarinic acid }\end{array}$ & S. mutans DSM 20523 & $\begin{array}{l}\text { MIC } \\
\text { MBC }\end{array}$ & $\begin{array}{l}0.60 \mathrm{mg} \cdot \mathrm{mL}^{-1} \\
2.50 \mathrm{mg} \cdot \mathrm{mL}^{-1}\end{array}$ & $>90 \%$ inhibition & $1.25 \mathrm{mg} \cdot \mathrm{mL}^{-1}$ & [200] \\
\hline & Extract (leaves) & & S. mutans ATCC 35688 & & - & $\begin{array}{l}32 \% \text { reduction of } \\
\text { total biofilm protein }\end{array}$ & $200 \mathrm{mg} \cdot \mathrm{mL}^{-1}$ & [224] \\
\hline Salvadora persica L. & Methanol & $\begin{array}{c}\text { Benzyl (6Z,9Z,12Z)- } \\
\text { 6,9,12-octadecatrienoate; } \\
\text { 3-benzyloxy-1-nitro- } \\
\text { butan-2-ol; } \\
\text { 1,3-cyclohexane } \\
\text { dicarbohydrazide }\end{array}$ & S. mutans $\mathrm{CI}$ & $\begin{array}{l}\text { MIC } \\
\text { IZD }\end{array}$ & $\begin{array}{c}2.60 \mathrm{mg} \cdot \mathrm{mL}^{-1} \\
24.0 \mathrm{~mm}\left(2.5 \mathrm{~g} \cdot \mathrm{mL}^{-1}\right)\end{array}$ & $87.9 \%$ inhibition & $2.6 \mathrm{mg} \cdot \mathrm{mL}^{-1}$ & [225] \\
\hline Salvia sclarea $\mathrm{L}$. & $\begin{array}{l}\text { Methanol (aerial plant } \\
\text { parts) }\end{array}$ & Rosmarinic acid & S. mutans DSM 20523 & $\begin{array}{l}\text { MIC } \\
\text { MBC }\end{array}$ & $\begin{array}{l}1.25 \mathrm{mg} \cdot \mathrm{mL}^{-1} \\
5.0 \mathrm{mg} \cdot \mathrm{mL}^{-1}\end{array}$ & $60 \%$ inhibition & $2.5 \mathrm{mg} \cdot \mathrm{mL}^{-1}$ & [200] \\
\hline $\begin{array}{l}\text { Schinus terebinthifolia } \\
\text { Raddi. }\end{array}$ & Methanol (leaves) & $p$-anisaldehyde & S. mutans UA159 & & - & $41 \%$ inhibition & $0.0035 \mathrm{mg} \cdot \mathrm{mL}^{-1}$ & [201] \\
\hline Sophora flavescens Aiton. & Methyl-alcohol & - & S mutans ATCC 25175 & MIC & $62.5 \mathrm{mg} \cdot \mathrm{mL}^{-1}$ & $\approx 88.5 \%$ reduction & $125 \mathrm{mg} \cdot \mathrm{mL}^{-1}$ & [195] \\
\hline $\begin{array}{l}\text { Spirostachys africana } \\
\text { Sond. }\end{array}$ & $\begin{array}{l}\text { Dichloromethane: } \\
\text { methanol (leaves) }\end{array}$ & - & S. mutans ATCC 25175 & MIC & $0.50 \mathrm{mg} \cdot \mathrm{mL}^{-1}$ & $97.56 \%$ inhibition & $0.25 \mathrm{mg} \cdot \mathrm{mL}^{-1}$ & [183] \\
\hline
\end{tabular}


Table 1. Cont.

\begin{tabular}{|c|c|c|c|c|c|c|c|c|}
\hline \multirow{2}{*}{ Plant Name } & \multirow{2}{*}{ Plant Extract } & \multirow{2}{*}{ Compound } & \multirow{3}{*}{$\begin{array}{c}\text { Microorganism } \\
\text { P. gingivalis ATCC } 53978 \\
\text { F. nucleatum ATCC } 25586\end{array}$} & \multicolumn{4}{|c|}{ Results } & \multirow{3}{*}{$\begin{array}{c}\text { References } \\
{[198]}\end{array}$} \\
\hline & & & & & nicrobial Activity & Antibiofil & Activity & \\
\hline \multirow{4}{*}{$\begin{array}{l}\text { Syzygium aromaticum (L.) } \\
\text { Merr. \& L.M.Perry }\end{array}$} & $\begin{array}{l}\text { Essential oil (flower } \\
\text { buds) }\end{array}$ & - & & & - & $\begin{array}{l}78.6 \% \text { inhibition } \\
76.2 \% \text { reduction }\end{array}$ & $\begin{array}{c}5.0 \mathrm{mg} \cdot \mathrm{mL}^{-1} \\
1.25 \mathrm{mg} \cdot \mathrm{mL}^{-1}\end{array}$ & \\
\hline & Ethanol & $\begin{array}{l}\text { Eugenol; eugenol acetate; } \\
\beta \text {-caryophyllene }\end{array}$ & $\begin{array}{l}\text { P. gingivalis JCM12257 } \\
\text { S. mutans NBRC13955 }\end{array}$ & & - & $\begin{array}{l}\text { MBEC } \\
\text { MBEC }\end{array}$ & $\begin{array}{c}435.5 \mu \mathrm{g} \cdot \mathrm{mL}^{-1} \\
871 \mu \mathrm{g} \cdot \mathrm{mL}^{-1}\end{array}$ & [151] \\
\hline & Essential oil & $\begin{array}{c}\text { Eugenol; } \\
\beta \text {-caryophyllene }\end{array}$ & $\begin{array}{l}\text { S. mutans ATCC } 25175 \\
\text { S. aureus ATCC } 29213 \\
\text { E. faecalis ATCC } 19433\end{array}$ & $\begin{array}{l}\text { MIC } \\
\text { IZD } \\
\text { MIC } \\
\text { IZD } \\
\text { MIC } \\
\text { IZD }\end{array}$ & $\begin{array}{c}0.315 \mathrm{mg} \cdot \mathrm{mL}^{-1} \\
5 \mathrm{~mm}\left(50 \mathrm{mg} \cdot \mathrm{mL}^{-1}\right) \\
0.625 \mathrm{mg} \cdot \mathrm{mL}^{-1} \\
6 \mathrm{~mm}\left(50 \mathrm{mg} \cdot \mathrm{mL}^{-1}\right) \\
1.25 \mathrm{mg} \cdot \mathrm{mL}^{-1} \\
1 \mathrm{~mm}\left(50 \mathrm{mg} \cdot \mathrm{mL}^{-1}\right)\end{array}$ & $\begin{array}{l}96 \% \text { reduction } \\
94 \% \text { reduction } \\
45 \% \text { reduction }\end{array}$ & $\begin{array}{l}1.26 \mathrm{mg} \cdot \mathrm{mL}^{-1} \\
2.5 \mathrm{mg} \cdot \mathrm{mL}^{-1} \\
5.0 \mathrm{mg} \cdot \mathrm{mL}^{-1}\end{array}$ & [185] \\
\hline & Hydroethanol (buds) & $\begin{array}{c}\text { Eugenol; } \\
\beta \text {-caryophyllene; } \\
\text { eugenol acetate }\end{array}$ & E. faecalis ATCC 29212 & $\begin{array}{l}\text { MBC } \\
\text { IZD }\end{array}$ & $\begin{array}{c}10 \%(w / v) \\
5.467 \mathrm{~mm}(20 \%(w / v))\end{array}$ & $100 \%$ reduction & $10 \%(w / v)$ & [226] \\
\hline $\begin{array}{l}\text { Tarchonanthus } \\
\text { camphoratus L. }\end{array}$ & $\begin{array}{l}\text { Dichloromethane: } \\
\text { methanol (bark) }\end{array}$ & - & S. mutans ATCC 25175 & MIC & $0.67 \mathrm{mg} \cdot \mathrm{mL}^{-1}$ & $86.37 \%$ inhibition & $0.08 \mathrm{mg} \cdot \mathrm{mL}^{-1}$ & [183] \\
\hline $\begin{array}{l}\text { Tecoma capensis } \\
\text { (Thunb.) Lindl. }\end{array}$ & $\begin{array}{l}\text { Dichloromethane: } \\
\text { methanol (leaves) }\end{array}$ & - & S. mutans ATCC 25175 & MIC & $0.67 \mathrm{mg} \cdot \mathrm{mL}^{-1}$ & $53.10 \%$ inhibition & $0.25 \mathrm{mg} \cdot \mathrm{mL}^{-1}$ & [183] \\
\hline Thuja orientalis $\mathrm{L}$. & $\begin{array}{l}\text { Methanol (leaves and } \\
\text { stems) }\end{array}$ & - & S. mutans ATCC 25175 & $\begin{array}{l}\text { MIC } \\
\text { IZD }\end{array}$ & $\begin{array}{c}0.1 \mathrm{mg} \cdot \text { disk }^{-1} \\
13 \mathrm{~mm}\left(2.0 \mathrm{mg} \cdot \text { disk }^{-1}\right)\end{array}$ & $\begin{array}{l}99.0 \% \text { GTFs } \\
\text { inhibition }\end{array}$ & $1.0 \mathrm{mg} \cdot \mathrm{mL}^{-1}$ & [125] \\
\hline $\begin{array}{l}\text { Thymus longicaulis } \\
\text { C.Presl. }\end{array}$ & Methanol (aerial parts) & $\begin{array}{c}\text { Rosmarinic acids; } \\
\text { flavonoids; triterpenic } \\
\text { acids }\end{array}$ & S. mutans DSM 20523 & $\begin{array}{l}\text { MIC } \\
\text { MBC }\end{array}$ & $\begin{array}{l}0.60 \mathrm{mg} \cdot \mathrm{mL}^{-1} \\
1.25 \mathrm{mg} \cdot \mathrm{mL}^{-1}\end{array}$ & $95 \%$ inhibition & $5.0 \mathrm{mg} \cdot \mathrm{mL}^{-1}$ & [200] \\
\hline
\end{tabular}


Table 1. Cont.

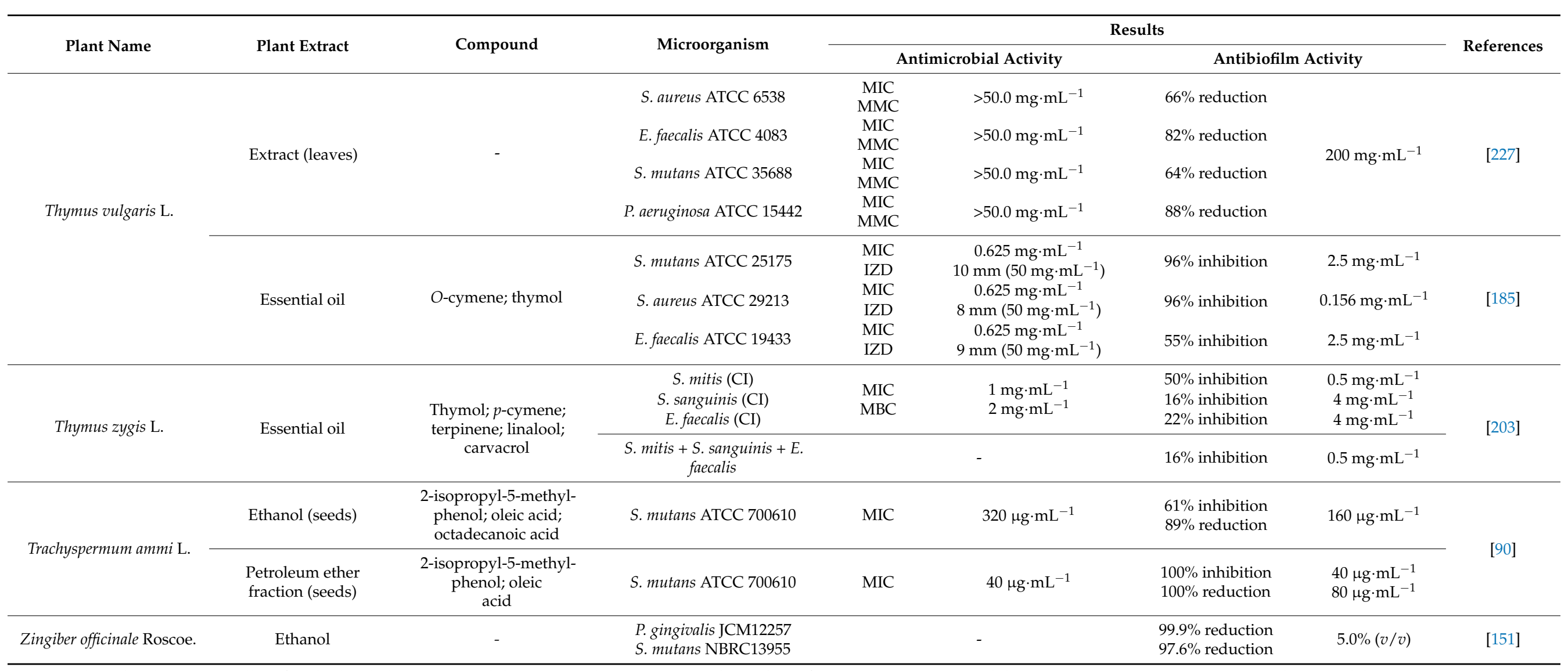

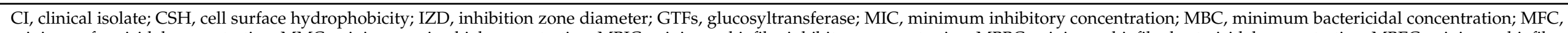

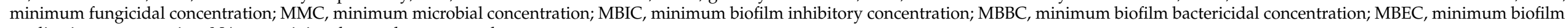
eradication concentration; NA, no activity observed; -, not tested. 


\section{Conclusions}

Medicinal plants are still a greatly unexplored source of powerful natural products with antibiofilm potential, especially when antibiotic resistances continue to rise. The focus of this review was to emphasize the potential of extracted products from medicinal plants such as essential oils and plant extracts, to treat common oral diseases, like dental caries and periodontitis, which are mainly caused by the formation of bacterial oral biofilms. Although the extracts of many medicinal plants have shown promising results in the control of oral biofilms, the two most promising extracts exerting this activity were found to be the essential oils extracted from two aromatic plants, namely C. citratus and L. alba. Interestingly, the terpenoid citral is one of the main components found in both plants, which is in accordance with several studies that point the powerful antibiofilm effect of this compound. The use of essential oils from C. citratus and L. alba could be a great alternative to antibiotics in the treatment of oral diseases since they show low cytotoxicity levels and do not induce resistance in bacterial pathogens. Nonetheless, research regarding the use of medicinal plants on the treatment of oral ailments continues to be an extremely interesting topic, mainly due to the extensive variety of unscreened plants that potentially have antimicrobial and antibiofilm properties.

Author Contributions: Conceptualization C.M., J.S., R.G.; methodology C.M., J.S., R.G.; data collection C.M., J.S., R.G.; writing-original draft preparations; C.M., J.S., R.G., writing-review and editing I.C.F.R.F., L.B.; supervision, M.J.A. All authors have read and agreed to the published version of the manuscript.

Funding: The authors wish to acknowledge financial support from the project "AquaValor-Centro de Valorização e Transferência de Tecnologia da Água" (NORTE-01-0246-FEDER-000053), supported by Norte Portugal Regional Operational Programme (NORTE 2020), under the PORTUGAL 2020 Partnership Agreement, through the European Regional Development Fund (ERDF); to the Foundation for Science and Technology (FCT, Portugal) for financial support through national funds FCT / MCTES to CIMO (UIDB/00690/2020); and L. Barros thanks the national funding by FCT, P.I., through the institutional scientific employment program-contract for her contract.

Institutional Review Board Statement: Not applicable.

Informed Consent Statement: Not applicable.

Data Availability Statement: Not applicable.

Conflicts of Interest: The authors declare no conflict of interest.

\section{References}

1. Marsh, P. Dental plaque as a microbial biofilm. Caries Res. 2004, 38, 204-211. [CrossRef]

2. Chinsembu, K.C. Plants and other natural products used in the management of oral infections and improvement of oral health. Acta Trop. 2016, 154, 6-18. [CrossRef] [PubMed]

3. Hwang, G.; Klein, M.I.; Koo, H. Analysis of the mechanical stability and surface detachment of mature Streptococcus mutans biofilms by applying a range of external shear forces. Biofouling 2014, 30, 1079-1091. [CrossRef]

4. Nishikawara, F.; Nomura, Y.; Imai, S.; Senda, A.; Hanada, N. Evaluation of cariogenic bacteria. Eur. J. Dent. 2007, 1, 31-39. [CrossRef] [PubMed]

5. Allaker, R.P.; Douglas, C.I. Novel anti-microbial therapies for dental plaque-related diseases. Int. J. Antimicrob. Agents 2009, 33, 8-13. [CrossRef] [PubMed]

6. Maeda, H.; Hirai, K.; Mineshiba, J.; Yamamoto, T.; Kokeguchi, S.; Takashiba, S. Medical microbiological approach to Archaea in oral infectious diseases. Jpn. Dent. Sci. Rev. 2013, 49, 72-78. [CrossRef]

7. Loesche, W. Dental caries and periodontitis: Contrasting two infections that have medical implications. Infect. Dis. Clin. N. Am. 2007, 21, 471-502. [CrossRef] [PubMed]

8. Alireza, R.G.; Afsaneh, R.; Hosein, M.S.; Siamak, Y.; Afshin, K.; Zeinab, K.; Mahvash, M.J.; Reza, R.A. Inhibitory activity of Salvadora persica extracts against oral bacterial strains associated with periodontitis: An in-vitro study. J. Oral Biol. Craniofac. Res. 2014, 4, 19-23. [CrossRef]

9. Galvão, L.C.; Furletti, V.F.; Bersan, S.M.; da Cunha, M.G.; Ruiz, A.L.; Carvalho, J.E.; Sartoratto, A.; Rehder, V.L.; Figueira, G.M.; Teixeira Duarte, M.C.; et al. Antimicrobial activity of essential oils against Streptococcus mutans and their antiproliferative effects. Evid.-Based Complement. Altern. Med. 2012, 2012, 751435. [CrossRef] 
10. Teanpaisan, R.; Kawsud, P.; Pahumunto, N.; Puripattanavong, J. Screening for antibacterial and antibiofilm activity in Thai medicinal plant extracts against oral micro-organisms. J. Tradit. Complement. Med. 2017, 7, 172-177. [CrossRef]

11. Vieira, D.R.; Amaral, F.M.; Maciel, M.C.; Nascimento, F.R.; Libério, S.A.; Rodrigues, V.P. Plant species used in dental diseases: Ethnopharmacology aspects and antimicrobial activity evaluation. J. Ethnopharmacol. 2014, 155, 1441-1449. [CrossRef]

12. Brown, D. Antibiotic resistance breakers: Can repurposed drugs fill the antibiotic discovery void? Nat. Rev. Drug Discov. 2015, 14, 821-832. [CrossRef]

13. Rana, R.; Sharma, R.; Kumar, A. Repurposing of existing statin drugs for treatment of microbial infections: How much promising? Infect. Disord. Drug Targets 2019, 19, 224-237. [CrossRef]

14. Palombo, E.A. Traditional medicinal plant extracts and natural products with activity against oral bacteria: Potential applica-tion in the prevention and treatment of oral diseases. Evid.-Based Complement. Altern. Med. 2011, 2011, 680354. [CrossRef] [PubMed]

15. Slobodníková, L.; Fialová, S.; Rendeková, K.; Kováč, J.; Mučaji, P. Antibiofilm activity of plant polyphenols. Molecules 2016, 21, 1717. [CrossRef] [PubMed]

16. Daglia, M. Polyphenols as antimicrobial agents. Curr. Opin. Biotechnol. 2012, 23, 174-181. [CrossRef] [PubMed]

17. Quideau, S.; Deffieux, D.; Douat-Casassus, C.; Pouységu, L. Plant polyphenols: Chemical properties, biological activities, and synthesis. Angew. Chem. Int. Ed. 2011, 50, 586-621. [CrossRef]

18. Cushnie, T.T.; Lamb, A.J. Recent advances in understanding the antibacterial properties of flavonoids. Int. J. Antimicrob. Agents 2011, 38, 99-107. [CrossRef] [PubMed]

19. Gyawali, R.; Ibrahim, S.A. Natural products as antimicrobial agents. Food Control 2014, 46, 412-429. [CrossRef]

20. Silva, L.N.; Zimmer, K.R.; Macedo, A.J.; Trentin, D.S. Plant natural products targeting bacterial virulence factors. Chem. Rev. 2016, 116, 9162-9236. [CrossRef]

21. Ren, Z.; Chen, L.; Li, J.; Li, Y. Inhibition of Streptococcus mutans polysaccharide synthesis by molecules targeting glycosyltransferase activity. J. Oral Microbiol. 2016, 8, 31095. [CrossRef] [PubMed]

22. Koparde, A.A.; Doijad, R.C.; Magdum, C.S. Natural products in drug discovery. In Pharmacognosy—Medicinal Plants; IntechOpen: London, UK, 2019.

23. Wade, W.G. Characterisation of the human oral microbiome. J. Oral Biosci. 2013, 55, 143-148. [CrossRef]

24. Dewhirst, F.E.; Chen, T.; Izard, J.; Paster, B.J.; Tanner, A.C.R.; Yu, W.-H.; Lakshmanan, A.; Wade, W.G. The human oral microbiome. J. Bacteriol. 2010, 192, 5002-5017. [CrossRef] [PubMed]

25. Lurie-Weinberger, M.N.; Gophna, U. Archaea in and on the human body: Health implications and future directions. PLoS Pathog. 2015, 11, e1004833. [CrossRef] [PubMed]

26. Agrawal, A.; Singh, A.; Verma, R.; Murari, A. Oral candidiasis: An overview. J. Oral Maxillofac. Pathol. 2014, 18, 81-85. [CrossRef]

27. Ghannoum, M.A.; Jurevic, R.J.; Mukherjee, P.K.; Cui, F.; Sikaroodi, M.; Naqvi, A.; Gillevet, P.M. Characterization of the oral fungal microbiome (Mycobiome) in healthy individuals. PLoS Pathog. 2010, 6, e1000713. [CrossRef]

28. Santosh, A.B.R.; Muddana, K. Viral infections of oral cavity. J. Fam. Med. Prim. Care 2020, 9, 36-42. [CrossRef]

29. Sharma, N.; Bhatia, S.; Sodhi, A.S.; Batra, N. Oral microbiome and health. AIMS Microbiol. 2018, 4, 42-66. [CrossRef]

30. Deo, P.N.; Deshmukh, R. Oral microbiome: Unveiling the fundamentals. J. Oral Maxillofac. Pathol. 2019, 23, 122-128. [CrossRef]

31. Lamont, R.J.; Koo, H.; Hajishengallis, G. The oral microbiota: Dynamic communities and host interactions. Nat. Rev. Genet. 2018, 16, 745-759. [CrossRef]

32. Loesche, W.J. Role of Streptococcus mutans in human dental decay. Microbiol. Rev. 1986, 50, 353. [CrossRef]

33. Marsh, P.D. Microbiology of dental plaque biofilms and their role in oral health and caries. Dent. Clin. N. Am. 2010, 54, 441-454. [CrossRef] [PubMed]

34. McNeill, K.; Hamilton, I. Acid tolerance response of biofilm cells of Streptococcus mutans. FEMS Microbiol. Lett. 2003, 221, 25-30. [CrossRef]

35. Dahlen, G.; Basic, A.; Bylund, J. Importance of virulence factors for the persistence of oral bacteria in the inflamed gingival crevice and in the pathogenesis of periodontal disease. J. Clin. Med. 2019, 8, 1339. [CrossRef]

36. Hannig, M.; Joiner, A. The structure, function and properties of the acquired pellicle. Monogr. Oral Sci. 2005, 19, 29-64. [CrossRef]

37. Bos, R.; Van der Mei, H.C.; Busscher, H.J. Physico-chemistry of initial microbial adhesive interactions-Its mechanisms and methods for study. FEMS Microbiol. Rev. 1999, 23, 179-230. [CrossRef]

38. Scannapieco, F.A.; Torres, G.; Levine, M.J. Salivary $\alpha$-amylase: Role in dental plaque and caries formation. Crit. Rev. Oral Biol. Med. 1993, 4, 301-307. [CrossRef]

39. Ihara, Y.; Takeshita, T.; Kageyama, S.; Matsumi, R.; Asakawa, M.; Shibata, Y.; Sugiura, Y.; Ishikawa, K.; Takahashi, I.; Yamashita, Y. Identification of initial colonizing bacteria in dental plaques from young adults using full-length 16S rRNA gene sequencing. mSystems 2019, 4, e00360-19. [CrossRef]

40. Vitkov, L.; Krautgartner, W.D.; Hannig, M.; Fuchs, K. Fimbria-mediated bacterial adhesion to human oral epithelium. FEMS Microbiol. Lett. 2001, 202, 25-30. [CrossRef]

41. Okahashi, N.; Nakata, M.; Terao, Y.; Isoda, R.; Sakurai, A.; Sumitomo, T.; Yamaguchi, M.; Kimura, R.K.; Oiki, E.; Kawabata, S.; et al. Pili of oral Streptococcus sanguinis bind to salivary amylase and promote the biofilm formation. Microb. Pathog. 2011, 50, 148-154. [CrossRef]

42. Karygianni, L.; Ren, Z.; Koo, H.; Thurnheer, T. Biofilm matrixome: Extracellular components in structured microbial communities. Trends Microbiol. 2020, 28, 668-681. [CrossRef] [PubMed] 
43. Costa, O.Y.A.; Raaijmakers, J.M.; Kuramae, E.E. Microbial extracellular polymeric substances: Ecological function and impact on soil aggregation. Front. Microbiol. 2018, 9, 1636. [CrossRef]

44. Rickard, A.H.; Gilbert, P.; High, N.J.; E Kolenbrander, P.; Handley, P.S. Bacterial coaggregation: An integral process in the development of multi-species biofilms. Trends Microbiol. 2003, 11, 94-100. [CrossRef]

45. Rabin, N.; Zheng, Y.; Opoku-Temeng, C.; Du, Y.; Bonsu, E.; O Sintim, H. Biofilm formation mechanisms and targets for developing antibiofilm agents. Future Med. Chem. 2015, 7, 493-512. [CrossRef] [PubMed]

46. Kaplan, J. Biofilm dispersal: Mechanisms, clinical implications, and potential therapeutic uses. J. Dent. Res. 2010, 89, 205-218. [CrossRef] [PubMed]

47. Bowen, W.H.; Burne, R.A.; Wu, H.; Koo, H. Oral biofilms: Pathogens, matrix, and polymicrobial interactions in microenvironments. Trends Microbiol. 2018, 26, 229-242. [CrossRef] [PubMed]

48. Suppiger, S.; Astasov-Frauenhoffer, M.; Schweizer, I.; Waltimo, T.; Kulik, E.M. Tolerance and persister formation in oral streptococci. Antibiotics 2020, 9, 167. [CrossRef] [PubMed]

49. Peres, M.A.; Macpherson, L.M.D.; Weyant, R.J.; Daly, B.; Venturelli, R.; Mathur, M.R.; Listl, S.; Celeste, R.K.; Guarnizo-Herreño, C.C.; Kearns, C.; et al. Oral diseases: A global public health challenge. Lancet 2019, 394, 249-260. [CrossRef]

50. Maddi, A.; Scannapieco, F.A. Oral biofilms, oral and periodontal infections, and systemic disease. Am. J. Dent. 2013, 26, $249-254$.

51. Kouidhi, B.; Al Qurashi, Y.M.A.; Chaieb, K. Drug resistance of bacterial dental biofilm and the potential use of natural compounds as alternative for prevention and treatment. Microb. Pathog. 2015, 80, 39-49. [CrossRef]

52. Matsumoto-Nakano, M. Role of Streptococcus mutans surface proteins for biofilm formation. Jpn. Dent. Sci. Rev. 2018, 54, 22-29. [CrossRef] [PubMed]

53. Bowen, W.; Koo, H. Biology of Streptococcus mutans-derived glucosyltransferases: Role in extracellular matrix formation of cariogenic biofilms. Caries Res. 2011, 45, 69-86. [CrossRef] [PubMed]

54. Miller, M.B.; Bassler, B.L. Quorum sensing in bacteria. Annu. Rev. Microbiol. 2001, 55, 165-199. [CrossRef] [PubMed]

55. Colombo, A.; Tanner, A. The role of bacterial biofilms in dental caries and periodontal and peri-implant diseases: A historical perspective. J. Dent. Res. 2019, 98, 373-385. [CrossRef] [PubMed]

56. Mosaddad, S.A.; Tahmasebi, E.; Yazdanian, A.; Rezvani, M.B.; Seifalian, A.; Yazdanian, M.; Tebyanian, H. Oral microbial biofilms: An update. Eur. J. Clin. Microbiol. Infect. Dis. 2019, 38, 2005-2019. [CrossRef]

57. Santos, A.L.; Siqueira, J.F., Jr.; Rôças, I.N.; Jesus, E.C.; Rosado, A.S.; Tiedje, J.M. Comparing the bacterial diversity of acute and chronic dental root canal infections. PLoS ONE 2011, 6, e28088. [CrossRef]

58. Colombo, A.P.; do Souto, R.M.; da Silva-Boghossian, C.M.; Miranda, R.; Lourenço, T.G. Microbiology of oral biofilm-dependent diseases: Have we made significant progress to understand and treat these diseases? Curr. Oral Health Rep. 2015, 2, 37-47. [CrossRef]

59. Ricucci, D.; Siqueira, J.F., Jr. Biofilms and apical periodontitis: Study of prevalence and association with clinical and histopathologic findings. J. Endod. 2010, 36, 1277-1288. [CrossRef]

60. Socransky, S.S.; Haffajee, A.D.; Cugini, M.A.; Smith, C.; Kent, R.L., Jr. Microbial complexes in subgingival plaque. J. Clin. Periodontol. 1998, 25, 134-144. [CrossRef]

61. Bui, F.Q.; Almeida-Da-Silva, C.L.C.; Huynh, B.; Trinh, A.; Liu, J.; Woodward, J.; Asadi, H.; Ojcius, D.M. Association between periodontal pathogens and systemic disease. Biomed. J. 2019, 42, 27-35. [CrossRef]

62. Yao, Q.-W.; Zhou, D.-S.; Peng, H.-J.; Ji, P.; Liu, D.-S. Association of periodontal disease with oral cancer: A meta-analysis. Tumor Biol. 2014, 35, 7073-7077. [CrossRef] [PubMed]

63. Michaud, D.S.; Fu, Z.; Shi, J.; Chung, M. Periodontal disease, tooth loss, and cancer risk. Epidemiol. Rev. 2017, 39, 49-58. [CrossRef]

64. Inaba, H.; Sugita, H.; Kuboniwa, M.; Iwai, S.; Hamada, M.; Noda, T.; Morisaki, I.; Lamont, R.J.; Amano, A. Porphyromonas gingivalis promotes invasion of oral squamous cell carcinoma through induction of pro MMP 9 and its activation. Cell. Microbiol. 2014, 16, 131-145. [CrossRef] [PubMed]

65. Fukugaiti, M.H.; Ignacio, A.; Fernandes, M.R.; Júnior, U.R.; Nakano, V.; AvilaCampos, M.J. High occurrence of Fusobacterium nucleatum and Clostridium difficile in the intestinal microbiota of colorectal carcinoma patients. Braz. J. Microbiol. 2015, 46, 1135-1140. [CrossRef] [PubMed]

66. Castellarin, M.; Warren, R.L.; Freeman, J.D.; Dreolini, L.; Krzywinski, M.; Strauss, J.; Barnes, R.; Watson, P.; Allen-Vercoe, E.; Moore, R.A.; et al. Fusobacterium nucleatum infection is prevalent in human colorectal carcinoma. Genome Res. 2011, 22, 299-306. [CrossRef]

67. Mealey, B.L.; Ocampo, G.L. Diabetes mellitus and periodontal disease. Periodontol. 2000 2007, 44, 127-153. [CrossRef] [PubMed]

68. Teeuw, W.J.; Gerdes, V.E.A.; Loos, B.G. Effect of periodontal treatment on glycemic control of diabetic patients: A systematic review and meta-analysis. Diabetes Care 2010, 33, 421-427. [CrossRef] [PubMed]

69. Nishimura, F.; Iwamoto, Y.; Mineshiba, J.; Shimizu, A.; Soga, Y.; Murayama, Y. Periodontal Disease and diabetes mellitus: The role of tumor necrosis factor- $\alpha$ in a 2-way relationship. J. Periodontol. 2003, 74, 97-102. [CrossRef]

70. Kothari, M.; Spin-Neto, R.; Nielsen, J.F. Comprehensive oral-health assessment of individuals with acquired brain-injury in neuro-rehabilitation setting. Brain Inj. 2016, 30, 1103-1108. [CrossRef]

71. Akiyama, H.; Barger, S.; Barnum, S.; Bradt, B.; Bauer, J.; Cole, G.M.; Cooper, N.R.; Eikelenboom, P.; Emmerling, M.; Fiebich, B.L.; et al. Inflammation and Alzheimer's disease. Neurobiol. Aging 2000, 21, 383-421. [CrossRef] 
72. Kamer, A.R.; Craig, R.G.; Pirraglia, E.; Dasanayake, A.P.; Norman, R.G.; Boylan, R.J.; Nehorayoff, A.; Glodzik, L.; Brys, M.; de Leon, M.J. TNF- $\alpha$ and antibodies to periodontal bacteria discriminate between Alzheimer's disease patients and normal subjects. J. Neuroimmunol. 2009, 216, 92-97. [CrossRef] [PubMed]

73. Poole, S.; Singhrao, S.K.; Kesavalu, L.; Curtis, M.A.; Crean, S. Determining the presence of periodontopathic virulence factors in short-term postmortem Alzheimer's disease brain tissue. J. Alzheimers Dis. 2013, 36, 665-677. [CrossRef] [PubMed]

74. Bahekar, A.A.; Singh, S.; Saha, S.; Molnar, J.; Arora, R. The prevalence and incidence of coronary heart disease is significantly increased in periodontitis: A meta-analysis. Am. Heart J. 2007, 154, 830-837. [CrossRef]

75. Figuero, E.; Sánchez-Beltrán, M.; Cuesta-Frechoso, S.; Tejerina, J.M.; Del Castro, J.A.; Gutiérrez, J.M.; Herrera, D.; Sanz, M. Detection of periodontal bacteria in atheromatous plaque by nested polymerase chain reaction. J. Periodontol. 2011, 82, 1469-1477. [CrossRef] [PubMed]

76. Haraszthy, V.; Zambon, J.; Trevisan, M.; Zeid, M.; Genco, R. Identification of periodontal pathogens in atheromatous plaques. J. Periodontol. 2000, 71, 1554-1560. [CrossRef] [PubMed]

77. Nakano, K.; Inaba, H.; Nomura, R.; Nemoto, H.; Takeda, M.; Yoshioka, H.; Matsue, H.; Takahashi, T.; Taniguchi, K.; Amano, A.; et al. Detection of cariogenic streptococcus mutans in extirpated heart valve and atheromatous plaque specimens. J. Clin. Microbiol. 2006, 44, 3313-3317. [CrossRef] [PubMed]

78. Hajishengallis, G.; Wang, M.; Bagby, G.J.; Nelson, S. Importance of TLR2 in early innate immune response to acute pulmonary infection with Porphy-romonas gingivalis in mice. J. Immunol. 2008, 181, 4141-4149. [CrossRef]

79. Sonti, R.; Fleury, C. Fusobacterium necrophorum presenting as isolated lung nodules. Respir. Med. Case Rep. 2015, 15, 80-82. [CrossRef]

80. Williams, D.M.; Kerber, C.A.; Tergin, H.F. Unusual presentation of Lemierre's syndrome due to Fusobacterium nucleatum. J. Clin. Microbiol. 2003, 41, 3445-3448. [CrossRef]

81. Gomes-Filho, I.S.; De Oliveira, T.F.L.; Da Cruz, S.S.; Passos-Soares, J.D.S.; Trindade, S.C.; Oliveira, M.T.; Souza-Machado, A.; Cruz, A.A.; Barreto, M.L.; Seymour, G.J. Influence of periodontitis in the development of nosocomial pneumonia: A case control study. J. Periodontol. 2014, 85, e82-e90. [CrossRef]

82. Heo, S.M.; Sung, R.S.; Scannapieco, F.A.; Haase, E.M. Genetic relationships between Candida albicans strains isolated from dental plaque, trachea, and bron-choalveolar lavage fluid from mechanically ventilated intensive care unit patients. J. Oral Microbiol. 2011, 3, 6362. [CrossRef]

83. Tonetto, M.R.; Rocatto, G.; Matos, F.Z.; Pedro, F.M.; Lima, S.L.; Aranha, A.F.; Porto, A.N.; Borges, A.H.; Borba, A.M.; Patil, S.; et al. Periodontal and microbiological profile of intensive care unit inpatients. J. Contemp. Dent. Pract. 2016, 17, 807-814. [CrossRef]

84. Kaur, M.; Geisinger, M.L.; Geurs, N.C.; Griffin, R.; Vassilopoulos, P.J.; Vermeulen, L.; Haigh, S.; Reddy, M.S. Effect of intensive oral hygiene regimen during pregnancy on periodontal health, cytokine levels, and pregnancy outcomes: A pilot study. J. Periodontol. 2014, 85, 1684-1692. [CrossRef] [PubMed]

85. Lin, D.; Moss, K.; Beck, J.D.; Hefti, A.; Offenbacher, S. Persistently high levels of periodontal pathogens associated with preterm pregnancy outcome. J. Periodontol. 2007, 78, 833-841. [CrossRef] [PubMed]

86. Han, Y.; Wang, X. Mobile microbiome: Oral bacteria in extra-oral infections and inflammation. J. Dent. Res. 2013, 92, 485-491. [CrossRef] [PubMed]

87. Katz, J.; Chegini, N.; Shiverick, K.; Lamont, R. Localization of P. gingivalis in preterm delivery placenta. J. Dent. Res. 2009, 88, 575-578. [CrossRef] [PubMed]

88. Reyes, L.; Phillips, P.; Wolfe, B.; Golos, T.G.; Walkenhorst, M.; Progulske-Fox, A.; Brown, M. Porphyromonas gingivalis and adverse pregnancy outcome. J. Oral Microbiol. 2017, 9, 1374153. [CrossRef]

89. Potempa, J.; Mydel, P.; Koziel, J. The case for periodontitis in the pathogenesis of rheumatoid arthritis. Nat. Rev. Rheumatol. 2017, 13, 606-620. [CrossRef]

90. Khan, R.; Adil, M.; Danishuddin, M.; Verma, P.K.; Khan, A.U. In vitro and in vivo inhibition of Streptococcus mutans biofilm by Trachyspermum ammi seeds: An approach of alternative medicine. Phytomedicine 2012, 19, 747-755. [CrossRef]

91. Tiwari, R.; Rana, C. Plant secondary metabolites: A review. Int. J. Eng. Res. Gen. Sci. 2015, 3, 661-670.

92. Gorlenko, C.L.; Kiselev, H.Y.; Budanova, E.V.; Zamyatnin, A.A.; Ikryannikova, L.N. Plant secondary metabolites in the battle of drugs and drug-resistant bacteria: New heroes or worse clones of antibiotics? Antibiotics 2020, 9, 170. [CrossRef] [PubMed]

93. Hussein, R.A.; El-Anssary, A.A. Plants secondary metabolites: The key drivers of the pharmacological actions of medicinal plants. Herb. Med. 2019, 1, 13. [CrossRef]

94. Anand, U.; Jacobo-Herrera, N.; Altemimi, A.; Lakhssassi, N. A comprehensive review on medicinal plants as antimicrobial therapeutics: Potential avenues of biocompatible drug discovery. Metabolites 2019, 9, 258. [CrossRef]

95. Boudet, A.-M. Evolution and current status of research in phenolic compounds. Phytochemistry 2007, 68, 2722-2735. [CrossRef]

96. Cohen, S.D.; Kennedy, J.A. Plant metabolism and the environment: Implications for managing phenolics. Crit. Rev. Food Sci. Nutr. 2010, 50, 620-643. [CrossRef]

97. Zahin, M.; Aqil, F.; Khan, M.S.; Ahmad, I. Ethnomedicinal plants derived antibacterials and their prospects. In Ethnomedicine: A Source of Complementary Therapeutics; Research Signpost: Thiruvananthapuram, India, 2010; pp. 149-178.

98. Carocho, M.; Barreiro, M.F.; Morales, P.; Ferreira, I.C. Adding molecules to food, pros and cons: A review on synthetic and natural food additives. Compr. Rev. Food Sci. Food Saf. 2014, 13, 377-399. [CrossRef] 
99. Silva, N.; Júnior, A.F. Biological properties of medicinal plants: A review of their antimicrobial activity. J. Venom. Anim. Toxins Incl. Trop. Dis. 2010, 16, 402-413. [CrossRef]

100. Hassan, B.A.R. Medicinal plants (importance and uses). Pharm. Anal. Acta 2012, 3, 2153-2435. [CrossRef]

101. Górniak, I.; Bartoszewski, R.; Króliczewski, J. Comprehensive review of antimicrobial activities of plant flavonoids. Phytochem. Rev. 2019, 18, 241-272. [CrossRef]

102. Zhang, L.; Kong, Y.; Wu, D.; Zhang, H.; Wu, J.; Chen, J.; Ding, J.; Hu, L.; Jiang, H.; Shen, X. Three flavonoids targeting the $\beta$-hydroxyacyl-acyl carrier protein dehydratase from Helicobacter pylori: Crystal structure characterization with enzymatic inhibition assay. Protein Sci. 2008, 17, 1971-1978. [CrossRef] [PubMed]

103. Taylor, P.W.; Hamilton-Miller, J.M.T.; Stapleton, P.D. Antimicrobial properties of green tea catechins. Food Sci. Technol. Bull. Funct. Foods 2005, 2, 71-81. [CrossRef] [PubMed]

104. Koo, H.; Hayacibara, M.F.; Schobel, B.D.; Cury, J.A.; Rosalen, P.L.; Park, Y.K.; Vacca-Smith, A.M.; Bowen, W.H. Inhibition of Streptococcus mutans biofilm accumulation and polysaccharide production by apigenin and tt-farnesol. J. Antimicrob. Chemother. 2003, 52, 782-789. [CrossRef] [PubMed]

105. Hasan, S.; Singh, K.; Danisuddin, M.; Verma, P.K.; Khan, A.U. Inhibition of major virulence pathways of Streptococcus mutans by quercitrin and deoxynojirimycin: A synergistic approach of infection control. PLoS ONE 2014, 9, e91736. [CrossRef]

106. Pagare, S.; Bhatia, M.; Tripathi, N.; Pagare, S.; Bansal, Y.K. Secondary metabolites of plants and their role: Overview. Curr. Trends Biotechnol. Pharm. 2015, 9, 293-304.

107. Fokialakis, N.; Skaltsounis, A.L. Natural resins and bioactive natural products thereof as potential anitimicrobial agents. Curr. Pharm. Des. 2011, 17, 1267-1290. [CrossRef]

108. Savoia, D. Plant-derived antimicrobial compounds: Alternatives to antibiotics. Futur. Microbiol. 2012, 7, 979-990. [CrossRef]

109. Bazaka, K.; Jacob, M.V.; Chrzanowski, W.; Ostrikov, K. Anti-bacterial surfaces: Natural agents, mechanisms of action, and plasma surface modification. RSC Adv. 2015, 5, 48739-48759. [CrossRef]

110. Sen, T.; Samanta, S.K. Medicinal plants, human health and biodiversity: A broad review. Adv. Biochem. Eng. Biotechnol. 2015, 147, 59-110.

111. Patel, D.M.; Chauhan, J.B.; Ishnava, K.B. Studies on the anticariogenic potential of medicinal plant seed and fruit extracts. In Natural Oral Care in Dental Therapy; Wiley: Hoboken, NJ, USA, 2020; pp. 81-96.

112. Cazella, L.N.; Glamoclija, J.; Soković, M.; Gonçalves, J.E.; Linde, G.A.; Colauto, N.B.; Gazim, Z.C. Antimicrobial activity of essential oil of Baccharis dracunculifolia DC (Asteraceae) aerial parts at flowering period. Front. Plant Sci. 2019, 10, 27. [CrossRef]

113. Boeing, T.; Costa, P.; Venzon, L.; Meurer, M.; Mariano, L.N.B.; França, T.C.S.; Gouveia, L.; De Bassi, A.C.; Steimbach, V.; De Souza, P.; et al. Gastric healing effect of p-coumaric acid isolated from Baccharis dracunculifolia DC on animal model. Naunyn-Schmiedebergs Arch. Pharmacol. 2021, 394, 49-57. [CrossRef]

114. Luchesi, L.A.; Paulus, D.; Busso, C.; Frata, M.T.; Oliveira, J.B. Chemical composition, antifungal and antioxidant activity of essential oils from Baccharis dracunculifolia and Pogostemon cablin against Fusarium graminearum. Nat. Prod. Res. 2020, 1-4. [CrossRef] [PubMed]

115. Lemos, M.; De Barros, M.P.; Sousa, J.P.B.; Filho, A.A.D.S.; Bastos, J.K.; De Andrade, S.F. Baccharis dracunculifolia, the main botanical source of Brazilian green propolis, displays antiulcer activity ${ }^{\dagger}$. J. Pharm. Pharmacol. 2010, 59, 603-608. [CrossRef] [PubMed]

116. Gilabert, M.; Ramos, A.N.; Schiavone, M.M.; Arena, M.E.; Bardoón, A. Bioactive sesqui- and diterpenoids from the Argentine Liverwort Porella chilensis. J. Nat. Prod. 2011, 74, 574-579. [CrossRef] [PubMed]

117. Lee, K.; Lee, J.-H.; Kim, S.-I.; Cho, M.H.; Lee, J. Anti-biofilm, anti-hemolysis, and anti-virulence activities of black pepper, cananga, myrrh oils, and nerolidol against Staphylococcus aureus. Appl. Microbiol. Biotechnol. 2014, 98, 9447-9457. [CrossRef]

118. Piao, M.J.; Yoo, E.S.; Koh, Y.S.; Kang, H.K.; Kim, J.; Kim, Y.J.; Kang, H.H.; Hyun, J.W. Antioxidant effects of the ethanol extract from flower of Camellia japonica via scavenging of reactive oxygen species and induction of antioxidant enzymes. Int. J. Mol. Sci. 2011, 12, 2618-2630. [CrossRef]

119. Kim, K.Y.; Davidson, P.M.; Chung, H.J. Antibacterial activity in extracts of Camellia japonica L. Petals and its application to a model food system. J. Food Prot. 2001, 64, 1255-1260. [CrossRef] [PubMed]

120. Nam, H.H.; Nan, L.; Choo, B.K. Inhibitory effects of Camellia japonica on cell inflammation and acute rat reflux esopha-gitis. Chin. Med. 2021, 16, 1-12. [CrossRef]

121. Zhang, Z.H.; Mi, C.; Wang, K.S.; Wang, Z.; Li, M.Y.; Zuo, H.X.; Xu, G.H.; Li, X.; Piao, L.X.; Ma, J.; et al. Chelidonine inhibits TNF- $\alpha$-induced inflammation by suppressing the NF-kB pathways in HCT116 cells. Phytother. Res. 2018, 32, 65-75. [CrossRef]

122. Dobrucka, R.; Dlugaszewska, J.; Kaczmarek, M. Cytotoxic and antimicrobial effects of biosynthesized ZnO nanoparticles using of Chelidonium majus extract. Biomed. Microdevices 2018, 20, 1-13. [CrossRef] [PubMed]

123. Kim, T.-H.; Li, H.; Wu, Q.; Lee, H.J.; Ryu, J.-H. A new labdane diterpenoid with anti-inflammatory activity from Thuja orientalis J. Ethnopharmacol. 2013, 146, 760-767. [CrossRef]

124. Chakraborty, S.; Afaq, N.; Singh, N.; Majumdar, S. Antimicrobial activity of Cannabis sativa, Thuja orientalis and Psidium guajava leaf extracts against methicillin-resistant Staphylococcus aureus. J. Integr. Med. 2018, 16, 350-357. [CrossRef]

125. Choi, H.-A.; Cheong, D.-E.; Lim, H.-D.; Kim, W.-H.; Ham, M.-H.; Oh, M.-H.; Wu, Y.; Shin, H.-J.; Kim, G.-J. Antimicrobial and anti-biofilm activities of the methanol extracts of medicinal plants against dental pathogens Streptococcus mutans and Candida albicans. J. Microbiol. Biotechnol. 2017, 27, 1242-1248. [CrossRef] 
126. Cushnie, T.T.; Lamb, A.J. Antimicrobial activity of flavonoids. Int. J. Antimicrob. Agents 2005, 26, 343-356. [CrossRef] [PubMed]

127. Xie, Y.; Yang, W.; Tang, F.; Chen, X.; Ren, L. Antibacterial activities of flavonoids: Structure-activity relationship and mechanism. Curr. Med. Chem. 2014, 22, 132-149. [CrossRef] [PubMed]

128. Dorri, M.; Hashemitabar, S.; Hosseinzadeh, H. Cinnamon (Cinnamomum zeylanicum) as an antidote or a protective agent against natural or chemical toxicities: A review. Drug Chem. Toxicol. 2018, 41, 338-351. [CrossRef]

129. Kerekes, E.B.; Vidács, A.; Takó, M.; Petkovits, T.; Vágvölgyi, C.; Horváth, G.; Balázs, V.L.; Krisch, J. Anti-biofilm effect of selected essential oils and main components on mono- and polymicrobic bacterial cultures. Microorganisms 2019, 7, 345. [CrossRef] [PubMed]

130. Bardají, D.; Reis, E.; Medeiros, T.; Lucarini, R.; Crotti, A.; Martins, C. Antibacterial activity of commercially available plant-derived essential oils against oral pathogenic bacteria. Nat. Prod. Res. 2015, 30, 1178-1181. [CrossRef]

131. Taguchi, Y.; Takizawa, T.; Ishibashi, H.; Sagawa, T.; Arai, R.; Inoue, S.; Yamaguchi, H.; Abe, S. Therapeutic effects on murine oral candidiasis by oral administration of Cassia (Cinnamomum cassia) preparation. Nippon. Ishinkin Gakkai Zasshi 2010, 51, 13-21. [CrossRef]

132. Ali, I.A.; Cheung, B.P.; Matinlinna, J.; Lévesque, C.M.; Neelakantan, P. Trans-cinnamaldehyde potently kills Enterococcus faecalis biofilm cells and prevents biofilm recovery. Microb. Pathog. 2020, 149, 104482. [CrossRef] [PubMed]

133. Durgadevi, R.; Ravi, A.V.; Alexpandi, R.; Swetha, T.K.; Abirami, G.; Vishnu, S.; Pandian, S.K. Virulence targeted inhibitory effect of linalool against the exclusive uropathogen Proteus mirabilis. Biofouling 2019, 35, 508-525. [CrossRef]

134. Kačániová, M.; Galovičová, L.; Ivanišová, E.; Vukovic, N.L.; Štefániková, J.; Valková, V.; Borotová, P.; Žiarovská, J.; Terentjeva, M.; Felšöciová, S.; et al. Antioxidant, antimicrobial and antibiofilm activity of coriander (Coriandrum sativum L.) essential oil for its application in foods. Foods 2020, 9, 282. [CrossRef]

135. Can, E.; Kizak, V.; Can, Ş.S.; Özçiçek, E. Anesthetic efficiency of three medicinal plant oils for aquatic species: Coriander Coriandrum sativum, linaloe tree Bursera delpechiana, and lavender Lavandula hybrida. J. Aquat. Anim. Health 2019, 31, 266-273. [CrossRef] [PubMed]

136. Bersan, S.M.F.; Galvão, L.C.C.; Goes, V.F.F.; Sartoratto, A.; Figueira, G.M.; Rehder, V.L.G.; Alencar, S.M.; Duarte, R.M.T.; Rosalen, P.L.; Duarte, M.C.T. Action of essential oils from Brazilian native and exotic medicinal species on oral biofilms. BMC Complement. Altern. Med. 2014, 14, 451. [CrossRef]

137. Mukherjee, K.; Tribedi, P.; Mukhopadhyay, B.; Sil, A.K. Antibacterial activity of long-chain fatty alcohols against mycobacteria. FEMS Microbiol. Lett. 2013, 338, 177-183. [CrossRef] [PubMed]

138. Ames-Sibin, A.P.; Barizão, C.L.; Castro-Ghizoni, C.V.; Silva, F.M.S.; Sá-Nakanishi, A.B.; Bracht, L.; Bersani-Amado, C.A.; MarçalNatali, M.R.; Bracht, A.; Comar, J.F. $\beta$-Caryophyllene, the major constituent of copaiba oil, reduces systemic inflammation and oxidative stress in arthritic rats. J. Cell. Biochem. 2018, 119, 10262-10277. [CrossRef] [PubMed]

139. Ribeiro, V.P.; Arruda, C.; Da Silva, J.J.M.; Mejia, J.A.A.; Furtado, N.A.J.C.; Bastos, J.K. Use of spinning band distillation equipment for fractionation of volatile compounds of Copaifera oleoresins for developing a validated gas chromatographic method and evaluating antimicrobial activity. Biomed. Chromatogr. 2019, 33, e4412. [CrossRef]

140. Símaro, G.V.; Lemos, M.; da Silva, J.J.M.; Ribeiro, V.P.; Arruda, C.; Schneider, A.H.; Wanderley, C.W.D.S.; Carneiro, L.J.; Mariano, R.L.; Ambrósio, S.R.; et al. Antinociceptive and anti-inflammatory activities of Copaifera pubiflora Benth oleoresin and its major metabolite ent-hardwickiic acid. J. Ethnopharmacol. 2021, 271, 113883. [CrossRef]

141. Moraes, T.D.S.; Leandro, L.F.; Santiago, M.B.; Silva, L.D.O.; Bianchi, T.C.; Veneziani, R.C.S.; Ambrósio, S.R.; Ramos, S.B.; Bastos, J.K.; Martins, C.H.G. Assessment of the antibacterial, antivirulence, and action mechanism of Copaifera pubiflora oleoresin and isolated compounds against oral bacteria. Biomed. Pharmacother. 2020, 129, 110467. [CrossRef]

142. Carneiro, L.J.; Tasso, T.O.; Santos, M.F.; Goulart, M.O.; Santos, R.A.; Bastos, J.K.; da Silva, J.J.; Crotti, A.E.; Parreira, R.L.; Orenha, R.P.; et al. Copaifera multijuga, Copaifera pubiflora and Copaifera trapezifolia Oleoresins: Chemical characterization and in vitro cytotoxic potential against tumoral cell lines. J. Braz. Chem. Soc. 2020, 31, 1679-1689. [CrossRef]

143. Ekpenyong, C.E.; Akpan, E.E. Use of Cymbopogon citratus essential oil in food preservation: Recent advances and future perspectives. Crit. Rev. Food Sci. Nutr. 2017, 57, 2541-2559. [CrossRef]

144. Hacke, A.C.M.; Miyoshi, E.; Marques, J.A.; Pereira, R.P. Anxiolytic properties of Cymbopogon citratus (DC.) stapf extract, essential oil and its constituents in zebrafish (Danio rerio). J. Ethnopharmacol. 2020, 260, 113036. [CrossRef]

145. Oliveira, J.B.; Teixeira, M.A.; Paiva, L.F.; Oliveira, R.F.; Mendonça, A.R.; Brito, M.J. In vitro and in vivo antimicrobial activity of Cymbopogon citratus (DC.) Stapf. against Staphylococcus spp. isolated from newborn babies in an intensive care unit. Microb. Drug Resist. 2019, 25, 1490-1496. [CrossRef]

146. Ortega-Ramirez, L.A.; Gutiérrez-Pacheco, M.M.; Vargas-Arispuro, I.; González-Aguilar, G.A.; Martínez-Téllez, M.A.; AyalaZavala, J.F. Inhibition of glucosyltransferase activity and glucan production as an antibiofilm mechanism of lemongrass essential oil against Escherichia coli O157:H7. Antibiotics 2020, 9, 102. [CrossRef]

147. Ortega-Cuadros, M.; Tofiño-Rivera, A.P.; Merini, L.J.; Martínez-Pabón, M.C. Antimicrobial activity of Cymbopogon citratus (Poaceae) on Streptococcus mutans biofilm and its cytotoxic effects. Rev. Biol. Trop. 2018, 66, 1519-1529. [CrossRef]

148. Tofiño-Rivera, A.; Ortega-Cuadros, M.; Galvis-Pareja, D.; Jiménez-Rios, H.; Merini, L.; Martínez-Pabón, M. Effect of Lippia alba and Cymbopogon citratus essential oils on biofilms of Streptococcus mutans and cytotoxicity in CHO cells. J. Ethnopharmacol. 2016, 194, 749-754. [CrossRef] [PubMed] 
149. Chaves-Quirós, C.; Usuga-Usuga, J.-S.; Morales-Uchima, S.-M.; Tofiño-Rivera, A.-P.; Tobón-Arroyave, S.-I.; Martínez-Pabón, M.-C.; Rivera, A.T. Assessment of cytotoxic and antimicrobial activities of two components of Cymbopogon citratus essential oil. J. Clin. Exp. Dent. 2020, 12, e749-e754. [CrossRef]

150. González-Burgos, E.; Liaudanskas, M.; Viškelis, J.; Žvikas, V.; Janulis, V.; Gómez-Serranillos, M.P. Antioxidant activity, neuroprotective properties and bioactive constituents analysis of varying polarity extracts from Eucalyptus globulus leaves. J. Food Drug Anal. 2018, 26, 1293-1302. [CrossRef] [PubMed]

151. Tsukatani, T.; Sakata, F.; Kuroda, R.; Akao, T. Biofilm eradication activity of herb and spice extracts alone and in combination against oral and food-borne pathogenic bacteria. Curr. Microbiol. 2020, 77, 2486-2495. [CrossRef]

152. Nagata, H.; Inagaki, Y.; Yamamoto, Y.; Maeda, K.; Kataoka, K.; Osawa, K.; Shizukuishi, S. Inhibitory effects of macrocarpals on the biological activity of Porphyromonas gingivalis and other periodontopathic bacteria. Oral Microbiol. Immunol. 2006, 21, 159-163. [CrossRef]

153. Sebei, K.; Sakouhi, F.; Herchi, W.; Khouja, M.L.; Boukhchina, S. Chemical composition and antibacterial activities of seven Eucalyptus species essential oils leaves. Biol. Res. 2015, 48, 1-5. [CrossRef] [PubMed]

154. Issarachot, P.; Sangkaew, W.; Sianglum, W.; Saeloh, D.; Limsuwan, S.; Voravuthikunchai, S.P.; Joycharat, N. $\alpha$-glucosidase inhibitory, antibacterial, and antioxidant activities of natural substances from the wood of Derris reticulata Craib. Nat. Prod. Res. 2019, 1-8. [CrossRef] [PubMed]

155. Pulbutr, P.; Rattanakiat, S.; Phetsaardeiam, N.; Modtaku, P.; Denchai, R.; Jaruchotikamol, A.; Khunawattanakul, W. Anticariogenic activities of Derris reticulata ethanolic stem extract against Streptococcus mutans. Pak. J. Biol. Sci. 2018, 21, 300-306. [CrossRef] [PubMed]

156. Getie, M.; Gebre-Mariam, T.; Rietz, R.; Höhne, C.; Huschka, C.; Schmidtke, M.; Abate, A.; Neubert, R. Evaluation of the antimicrobial and anti-inflammatory activities of the medicinal plants Dodonaea viscosa, Rumex nervosus and Rumex abyssinicus. Fitoterapia 2003, 74, 139-143. [CrossRef]

157. Khalil, N.; Sperotto, J.; Manfron, M. Antiinflammatory activity and acute toxicity of Dodonaea viscosa. Fitoterapia 2006, 77, 478-480. [CrossRef] [PubMed]

158. Qureshi, S.; Khan, M.; Ahmad, M. A survey of useful medicinal plants of Abbottabad in northern Pakistan. Trakia J. Sci. 2008, 6, 39-51.

159. Naidoo, R.; Patel, M.; Gulube, Z.; Fenyvesi, I. Inhibitory activity of Dodonaea viscosa var. angustifolia extract against Streptococcus mutans and its biofilm. J. Ethnopharmacol. 2012, 144, 171-174. [CrossRef] [PubMed]

160. Karkanis, A.; Martins, N.; Petropoulos, S.; Ferreira, I. Phytochemical composition, health effects, and crop management of liquorice (Glycyrrhiza glabra L.): A medicinal plant. Food Rev. Int. 2016, 34, 182-203. [CrossRef]

161. Chakotiya, A.S.; Tanwar, A.; Narula, A.; Sharma, R.K. Alternative to antibiotics against Pseudomonas aeruginosa: Effects of Glycyrrhiza glabra on membrane permeability and inhibition of efflux activity and biofilm formation in Pseudomonas aeruginosa and its in vitro time-kill activity. Microb. Pathog. 2016, 98, 98-105. [CrossRef]

162. Suwannakul, S.; Chaibenjawong, P. Antibacterial activities of Glycyrrhiza gabra Linn. (licorice) root extract against Porphyromonas gingivalis rand its inhibitory effects on cysteine proteases and biofilms. J. Dent. Indones. 2017, 24, 85-92. [CrossRef]

163. Kim, S.-R.; Jeon, H.-J.; Park, H.-J.; Kim, M.-K.; Choi, W.-S.; Jang, H.-O.; Bae, S.-K.; Jeong, C.-H.; Bae, M.-K. Glycyrrhetinic acid inhibits Porphyromonas gingivalis lipopolysaccharide-induced vascular permeability via the suppression of interleukin-8. Inflamm. Res. 2012, 62, 145-154. [CrossRef]

164. Hennebelle, T.; Sahpaz, S.; Joseph, H.; Bailleul, F. Ethnopharmacology of Lippia alba. J. Ethnopharmacol. 2008, 116, 211-222. [CrossRef]

165. Mączka, W.; Wińska, K.; Grabarczyk, M. One hundred faces of geraniol. Molecules 2020, 25, 3303. [CrossRef]

166. Nikavar, B.; Ali, N.A.; Kamalnezhad, M. Evaluation of the antioxidant properties of five Mentha species. Iran J. Pharm. Res. 2008. [CrossRef]

167. Shafiei, Z.; Rahim, Z.H.; Philip, K.; Thurairajah, N.; Yaacob, H. Potential effects of Psidium sp., Mangifera sp., Mentha sp. and its mixture (PEM) in reducing bacterial populations in biofilms, adherence and acid production of S. sanguinis and S. mutans. Arch. Oral Biol. 2020, 109, 104554. [CrossRef] [PubMed]

168. Wi, W.N.; Fathilah, A.; Rahim, Z. Plant extracts of Psidium guajava, Mangifera and Mentha sp. inhibit the growth of the population of single-species oral biofilm. Altern. Integr. Med. 2013, 31, 1-6.

169. Rahim, Z.H.A.; Shaikh, S.; Ismail, W.N.H.W.; Harun, W.H.-A.W.; Razak, F.A. The effect of selected plant extracts on the development of single-species dental biofilms. J. Coll. Physicians Surg. Pak. 2014, 24, 796-801. [PubMed]

170. Shafiei, Z.; Rahim, Z.H.; Philip, K.; Thurairajah, N. Antibacterial and anti-adherence effects of a plant extract mixture (PEM) and its individual constituent ex-tracts (Psidium sp., Mangifera sp., and Mentha sp.) on single- and dual-species biofilms. PeerJ 2016, 4, e2519. [CrossRef]

171. Aleksic, V.; Knezevic, P. Antimicrobial and antioxidative activity of extracts and essential oils of Myrtus communis L. Microbiol. Res. 2014, 169, 240-254. [CrossRef]

172. Kaya, D.A.; Ghica, M.V.; Dănilă, E.; Öztürk, Ş.; Türkmen, M.; Kaya, M.G.A.; Dinu-Pîrvu, C.-E. Selection of optimal operating conditions for extraction of Myrtus Communis L. essential oil by the steam distillation method. Molecules 2020, 25, 2399. [CrossRef] 
173. Sateriale, D.; Imperatore, R.; Colicchio, R.; Pagliuca, C.; Varricchio, E.; Volpe, M.G.; Salvatore, P.; Paolucci, M.; Pagliarulo, C. Phytocompounds vs. dental plaque bacteria: In vitro effects of myrtle and pomegranate polyphenolic extracts against single-species and multispecies oral biofilms. Front. Microbiol. 2020, 11, 11. [CrossRef]

174. Sateriale, D.; Facchiano, S.; Colicchio, R.; Pagliuca, C.; Varricchio, E.; Paolucci, M.; Volpe, M.G.; Salvatore, P.; Pagliarulo, C. In vitro synergy of polyphenolic extracts from honey, myrtle and pomegranate against oral pathogens, $\mathrm{S}$. mutans and R. dentocariosa. Front. Microbiol. 2020, 11, 1465. [CrossRef] [PubMed]

175. Panossian, A.; Wikman, G.; Sarris, J. Rosenroot (Rhodiola rosea): Traditional use, chemical composition, pharmacology and clinical efficacy. Phytomedicine 2010, 17, 481-493. [CrossRef] [PubMed]

176. Chiang, H.-M.; Chen, H.-C.; Wu, C.-S.; Wu, P.-Y.; Wen, K.-C. Rhodiola plants: Chemistry and biological activity. J. Food Drug Anal. 2015, 23, 359-369. [CrossRef] [PubMed]

177. Elameen, A.; Kosman, V.M.; Thomsen, M.; Pozharitskaya, O.N.; Shikov, A.N. Variability of major phenyletanes and phenylpropanoids in 16-year-old Rhodiola rosea L. clones in Norway. Molecules 2020, 25, 3463. [CrossRef]

178. Zhang, Z.; Liu, Y.; Lu, M.; Lyu, X.; Gong, T.; Tang, B.; Wang, L.; Zeng, J.; Li, Y. Rhodiola rosea extract inhibits the biofilm formation and the expression of virulence genes of cariogenic oral pathogen Streptococcus mutans. Arch. Oral Biol. 2020, 116, 104762. [CrossRef]

179. De Oliveira, J.R.; Camargo, S.E.A.; De Oliveira, L.D. Rosmarinus officinalis L. (rosemary) as therapeutic and prophylactic agent. J. Biomed. Sci. 2019, 26, 1-22. [CrossRef]

180. Birtić, S.; Dussort, P.; Pierre, F.-X.; Bily, A.C.; Roller, M. Carnosic acid. Phytochemistry 2015, 115, 9-19. [CrossRef]

181. Mirpour, M.; Siahmazgi, Z.G.; Kiasaraie, M.S. Antibacterial activity of clove, gall nut methanolic and ethanolic extracts on Streptococcus mutans PTCC 1683 and Streptococcus salivarius PTCC 1448. J. Oral Biol. Craniofacial Res. 2015, 5, 7-10. [CrossRef]

182. Philander, L.A. An ethnobotany of Western Cape Rasta bush medicine. J. Ethnopharmacol. 2011, 138, 578-594. [CrossRef]

183. Akhalwaya, S.; van Vuuren, S.; Patel, M. An in vitro investigation of indigenous South African medicinal plants used to treat oral infections. J. Ethnopharmacol. 2018, 210, 359-371. [CrossRef] [PubMed]

184. Nikolić, M.; Glamočlija, J.; Ferreira, I.C.; Calhelha, R.C.; Fernandes, Â.; Marković, T.; Marković, D.; Giweli, A.; Soković, M. Chemical composition, antimicrobial, antioxidant and antitumor activity of Thymus serpyllum L., Thymus algeriensis Boiss. and Reut and Thymus vulgaris L. essential oils. Ind. Crops Prod. 2014, 52, 183-190. [CrossRef]

185. De Oliveira Carvalho, I.; Purgato, G.A.; Píccolo, M.S.; Pizziolo, V.R.; Coelho, R.R.; Diaz-Muñoz, G.; Diaz, M.A.N. In vitro anticariogenic and antibiofilm activities of toothpastes formulated with essential oils. Arch. Oral Biol. 2020, 117, 104834. [CrossRef] [PubMed]

186. Dong, J.; Zhang, L.; Liu, Y.; Xu, N.; Zhou, S.; Yang, Q.; Yang, Y.; Ai, X. Thymol protects channel catfish from Aeromonas hydrophila infection by inhibiting aerolysin expression and biofilm formation. Microorganisms 2020, 8, 636. [CrossRef] [PubMed]

187. Hajiaghapour, M.; Rezaeipour, V. Comparison of two herbal essential oils, probiotic, and mannan-oligosaccharides on egg production, hatchability, serum metabolites, intestinal morphology, and microbiota activity of quail breeders. Livest. Sci. 2018, 210, 93-98. [CrossRef]

188. Vitali, L.A.; Beghelli, D.; Nya, P.C.B.; Bistoni, O.; Cappellacci, L.; Damiano, S.; Lupidi, G.; Maggi, F.; Orsomando, G.; Papa, F.; et al. Diverse biological effects of the essential oil from Iranian Trachyspermum ammi. Arab. J. Chem. 2016, 9, 775-786. [CrossRef]

189. Dahake, P.; Dadpe, M.; Dhore, S.; Kale, Y.; Kendre, S.; Siddiqui, A. Evaluation of antimicrobial efficacy of Trachyspermum ammi (Ajwain) oil and chlorhexidine against oral bacteria: An in vitro study. J. Indian Soc. Pedod. Prev. Dent. 2018, 36, 357-363. [CrossRef]

190. Murugan, K.; Sekar, K.; Sangeetha, S.; Ranjitha, S.; Sohaibani, S.A. Antibiofilm and quorum sensing inhibitory activity of Achyranthes aspera on cariogenic Streptococcus mutans: An in vitro and in silico study. Pharm. Biol. 2013, 51, 728-736. [CrossRef]

191. Yang, Y.; Hwang, E.-H.; Park, B.-I.; Choi, N.-Y.; Kim, K.-J.; You, Y.-O. Artemisia princeps inhibits growth, biofilm formation, and virulence factor expression of Streptococcus mutans. J. Med. Food 2019, 22, 623-630. [CrossRef]

192. Teanpaisan, R.; Senapong, S.; Puripattanavong, J. In vitro antimicrobial and antibiofilm activity of Artocarpus Lakoocha (Moraceae) extract against some oral pathogens. Trop. J. Pharm. Res. 2014, 13, 1149. [CrossRef]

193. Geethashri, A.; Manikandan, R.; Ravishankar, B.; Shetty, A.V. Comparative evaluation of biofilm suppression by plant extracts on oral pathogenic bacteria. J. Appl. Pharm. Sci. 2014, 4, 20.

194. Pereira, C.A.; Costa, A.C.B.P.; Liporoni, P.C.S.; Rego, M.A.; Jorge, A.O.C. Antibacterial activity of Baccharis dracunculifolia in planktonic cultures and biofilms of Streptococcus mutans. J. Infect. Public Health 2016, 9, 324-330. [CrossRef] [PubMed]

195. Lee, S.-H. Antimicrobial effects of herbal extracts on Streptococcus mutans and normal oral streptococci. J. Microbiol. 2013, 51, 484-489. [CrossRef] [PubMed]

196. Alshahrani, A.M.; Gregory, R.L. In vitro Cariostatic effects of cinnamon water extract on nicotine-induced Streptococcus mutans biofilm. BMC Complement. Med. Ther. 2020, 20, 1-9. [CrossRef] [PubMed]

197. Wiwattanarattanabut, K.; Choonharuangdej, S.; Srithavaj, T. In vitro anti-cariogenic plaque effects of essential oils extracted from culinary herbs. J. Clin. Diagn. Res. 2017, 11, DC30-DC35. [CrossRef]

198. Azizan, N.; Mohd-Said, S.; Mazlan, M.K.; Chelvan, K.T.; Hanafiah, R.M.; Zainal-Abidin, Z. In-vitro inhibitory effect of Cinnamomum zeylanicum and Eugenia caryophyllata oils on multispecies anaerobic oral biofilm. J. Int. Dent. Med. Res. 2019, 12, $411-417$. 
199. Wang, Y.; Zhang, Y.; Shi, Y.-Q.; Pan, X.-H.; Lu, Y.-H.; Cao, P. Antibacterial effects of cinnamon (Cinnamomum zeylanicum) bark essential oil on Porphyromonas gingivalis. Microb. Pathog. 2018, 116, 26-32. [CrossRef]

200. Hickl, J.; Argyropoulou, A.; Sakavitsi, M.E.; Halabalaki, M.; Al-Ahmad, A.; Hellwig, E.; Aligiannis, N.; Skaltsounis, A.L.; Wittmer, A.; Vach, K.; et al. Mediterranean herb extracts inhibit microbial growth of representative oral microorganisms and biofilm formation of Streptococcus mutans. PLoS ONE 2018, 13, e0207574. [CrossRef]

201. Barbieri, D.S.; Tonial, F.; Lopez, P.V.; Maia, B.H.; Santos, G.D.; Ribas, M.O.; Glienke, C.; Vicente, V.A. Antiadherent activity of Schinus terebinthifolius and Croton urucurana extracts on in vitro biofilm formation of Candida albicans and Streptococcus mutans. Arch. Oral Biol. 2014, 59, 887-896. [CrossRef]

202. Oliveira, M.A.; Borges, A.C.; Brighenti, F.L.; Salvador, M.J.; Gontijo, A.V.; Koga-Ito, C.Y. Cymbopogon citratus essential oil: Effect on polymicrobial caries-related biofilm with low cytotoxicity. Braz. Oral Res. 2017, 31, e89. [CrossRef] [PubMed]

203. Marinković, J.; Ćulafić, D.M.; Nikolić, B.; Đukanović, S.; Marković, T.; Tasić, G.; Ćirić, A.; Marković, D. Antimicrobial potential of irrigants based on essential oils of Cymbopogon martinii and Thymus zygis towards in vitro multispecies biofilm cultured in ex vivo root canals. Arch. Oral Biol. 2020, 117, 104842. [CrossRef] [PubMed]

204. Martos, J.; Luque, C.M.; González-Rodríguez, M.P.; Arias-Moliz, M.T.; Baca, P. Antimicrobial activity of essential oils and chloroform alone and combinated with cetrimide against Enterococcus faecalis biofilm. Eur. J. Microbiol. Immunol. 2013, 3, 44-48. [CrossRef] [PubMed]

205. Raoof, M.; Khaleghi, M.; Siasar, N.; Mohannadalizadeh, S.; Haghani, J.; Amanpour, S. Antimicrobial activity of methanolic extracts of Myrtus Communis L. and Eucalyptus Galbie and their combination with calcium hydroxide powder against Enterococcus Faecalis. J. Dent. Shiraz 2019, 20, 195-202.

206. Goldbeck, J.C.; Nascimento, J.E.D.; Jacob, R.G.; Fiorentini, Â.M.; da Silva, W.P. Bioactivity of essential oils from Eucalyptus globulus and Eucalyptus urograndis against planktonic cells and biofilms of Streptococcus mutans. Ind. Crops Prod. 2014, 60, 304-309. [CrossRef]

207. Sulistyani, H.; Fujita, M.; Miyakawa, H.; Nakazawa, F. Effect of roselle calyx extract on in vitro viability and biofilm formation ability of oral pathogenic bacteria. Asian Pac. J. Trop. Med. 2016, 9, 119-124. [CrossRef] [PubMed]

208. Sekita, Y.; Murakami, K.; Yumoto, H.; Amoh, T.; Fujiwara, N.; Ogata, S.; Matsuo, T.; Miyake, Y.; Kashiwada, Y. Preventive effects of Houttuynia cordata extract for oral infectious diseases. BioMed Res. Int. 2016, 2016, 2581876. [CrossRef]

209. Süntar, I.; Oyardı, O.; Akkol, E.K.; Ozçelik, B. Antimicrobial effect of the extracts from Hypericum perforatum against oral bacteria and biofilm formation. Pharm. Biol. 2016, 54, 1065-1070. [CrossRef]

210. Merghni, A.; Marzouki, H.; Hentati, H.; Aouni, M.; Mastouri, M. Antibacterial and antibiofilm activities of Laurus nobilis L. essential oil against Staphylococcus aureus strains associated with oral infections. Curr. Res. Transl. Med. 2016, 64, 29-34. [CrossRef]

211. Zhang, Z.; Zeng, J.; Zhou, X.; Xu, Q.; Li, C.; Liu, Y.; Zhang, C.; Wang, L.; Zeng, W.; Li, Y. Activity of Ligustrum robustum (Roxb.) Blume extract against the biofilm formation and exopolysaccharide synthesis of Streptococcus mutans. Mol. Oral Microbiol. 2021, 36, 67-79. [CrossRef]

212. Ahmad, I.; Wahab, S.; Nisar, N.; Dera, A.A.; Alshahrani, M.Y.; Abullias, S.S.; Irfan, S.; Alam, M.M.; Srivastava, S. Evaluation of antibacterial properties of Matricaria aurea on clinical isolates of periodontitis patients with special reference to red complex bacteria. Saudi Pharm. J. 2020, 28, 1203-1209. [CrossRef]

213. Nurrahman, H.F.; Widyarman, A.S. Effectiveness of Matricaria chamomilla essential oil on Aggregatibacter actinomycetemcomitans and Treponema denticola biofilms. J. Indones. Dent. Assoc. 2020, 3, 77-82.

214. Song, Y.-M.; Zhou, H.-Y.; Wu, Y.; Wang, J.; Liu, Q.; Mei, Y.-F. In vitro evaluation of the antibacterial properties of tea tree oil on planktonic and biofilm-forming Streptococcus mutans. AAPS PharmSciTech 2020, 21, 1-12. [CrossRef]

215. Ben Lagha, A.; Vaillancourt, K.; Huacho, P.M.; Grenier, D. Effects of labrador tea, peppermint, and winter savory essential oils on Fusobacterium nucleatum. Antibiotics 2020, 9, 794. [CrossRef]

216. Pires, J.G.; Zabini, S.S.; Braga, A.S.; de Cássia Fabris, R.; de Andrade, F.B.; de Oliveira, R.C.; Magalhães, A.C. Hydroalcoholic extracts of Myracrodruon urundeuva All. and Qualea grandiflora Mart. leaves on Streptococcus mutans biofilm and tooth demineralization. Arch. Oral Biol. 2018, 91, 17-22. [CrossRef] [PubMed]

217. Tsujii, T.; Kawada-Matsuo, M.; Migita, H.; Ohta, K.; Oogai, Y.; Yamasaki, Y.; Komatsuzawa, H. Antibacterial activity of phellodendron bark against Streptococcus mutans. Microbiol. Immunol. 2020, 64, 424-434. [CrossRef] [PubMed]

218. Orrù, G.; Demontis, C.; Mameli, A.; Tuveri, E.; Coni, P.; Pichiri, G.; Coghe, F.; Rosa, A.; Rossi, P.; D’Hallewin, G. The selective interaction of Pistacia lentiscus oil vs. human Streptococci, an old functional food revisited with new tools. Front. Microbiol. 2017, 8, 2067. [CrossRef] [PubMed]

219. Magi, G.; Marini, E.; Brenciani, A.; Di Lodovico, S.; Gentile, D.; Ruberto, G.; Cellini, L.; Nostro, A.; Facinelli, B.; Napoli, E. Chemical composition of Pistacia vera L. oleoresin and its antibacterial, anti-virulence and anti-biofilm activities against oral streptococci, including Streptococcus mutans. Arch. Oral Biol. 2018, 96, 208-215. [CrossRef] [PubMed]

220. Massunari, L.; Novais, R.Z.; Oliveira, M.T.; Valentim, D.; Junior, E.D.; Duque, C. Antimicrobial activity and biocompatibility of the Psidium cattleianum extracts for endodontic purposes. Braz. Dent. J. 2017, 28, 372-379. [CrossRef]

221. Dastjerdi, E.V.; Abdolazimi, Z.; Ghazanfarian, M.; Amdjadi, P.; Kamalinejad, M.; Mahboubi, A. Effect of Punica granatum L. flower water extract on five common oral bacteria and bacterial biofilm formation on orthodontic wire. Iran. J. Public Health 2014, $43,1688-1694$. 
222. De Sousa, M.B.; Júnior, J.O.; Barbosa, W.L.; da Silva Valério, E.; da Mata Lima, A.; de Araújo, M.H.; Muzitano, M.F.; Nakamura, C.V.; de Mello, J.C.; Teixeira, F.M. Pyrostegia venusta (Ker Gawl.) Miers crude extract and fractions: Prevention of dental biofilm formation and immunomodulatory capacity. Pharmacogn. Mag. 2016, 12, S218-S222.

223. De Oliveira, J.R.; de Jesus, D.; Figueira, L.W.; de Oliveira, F.E.; Pacheco Soares, C.; Camargo, S.E.; Jorge, A.O.; de Oliveira, L.D. Biological activities of Rosmarinus officinalis L.(rosemary) extract as analyzed in microorganisms and cells. Exp. Biol. Med. 2017, 242, 625-634. [CrossRef] [PubMed]

224. Oliveira, J.R.; Santana-Melo, G.D.; Camargo, S.E.; Vasconcellos, L.M.; Oliveira, L.D. Total protein level reduction of odontopathogens biofilms by Rosmarinus officinalis L. (rosemary) extract: An analysis on Candida albicans and Streptococcus mutans. Braz. Dent. Sci. 2019, 22, 260-266. [CrossRef]

225. Al-Sohaibani, S.; Murugan, K. Anti-biofilm activity of Salvadora persica on cariogenic isolates of Streptococcus mutans: In vitro and molecular docking studies. Biofouling 2012, 28, 29-38. [CrossRef] [PubMed]

226. Gupta, A.; Duhan, J.; Tewari, S.; Sangwan, P.; Yadav, A.; Singh, G.; Juneja, R.; Saini, H. Comparative evaluation of antimicrobial efficacy of Syzygium aromaticum, Ocimum sanctum and Cinnamomum zeylanicum plant extracts against Enterococcus faecalis: A preliminary study. Int. Endod. J. 2013, 46, 775-783. [CrossRef]

227. De Oliveira, J.R.; de Jesus Viegas, D.; Martins, A.P.; Carvalho, C.A.; Soares, C.P.; Camargo, S.E.; Jorge, A.O.; de Oliveira, L.D. Thymus vulgaris L. extract has antimicrobial and anti-inflammatory effects in the absence of cytotoxicity and genotoxicity. Arch. Oral Biol. 2017, 82, 271-279. [CrossRef] [PubMed] 